\title{
Review \\ Current Development and Application of Anaerobic Glycolytic Enzymes in Urothelial Cancer
}

\author{
Yi-Fang Yang ${ }^{1}\left(\mathbb{D}\right.$, Hao-Wen Chuang $\left.{ }^{2,3} \mathbb{(}\right)$, Wei-Ting Kuo ${ }^{4,5}$, Bo-Syuan Lin ${ }^{6}\left(\mathbb{D}\right.$ and Yu-Chan Chang ${ }^{6, *} \mathbb{(}$ \\ 1 Department of Medical Education and Research, Kaohsiung Veterans General Hospital, \\ Kaohsiung 81362, Taiwan; yvonne845040@gmail.com \\ 2 Department of Pathology and Laboratory Medicine, Kaohsiung Veterans General Hospital, \\ Kaohsiung 81362, Taiwan; hwchuang1980@gmail.com \\ 3 Institute of Oral Biology, School of Dentistry, National Yang Ming Chiao Tung University, \\ Taipei 11221, Taiwan \\ 4 Division of Urology, Department of Surgery, Kaohsiung Veterans General Hospital, Kaohsiung 81362, Taiwan; \\ kiwima0817@hotmail.com \\ 5 Institute of Clinical Medicine, National Yang Ming Chiao Tung University, Taipei 11221, Taiwan \\ 6 Department of Biomedical Imaging and Radiological Sciences, National Yang Ming Chiao Tung University, \\ Taipei 11221, Taiwan; a5375128@gmail.com \\ * Correspondence: jameskobe0@gmail.com; Tel.: +886-2-2826-7064
}

Citation: Yang, Y.-F.; Chuang, H.-W.; Kuo, W.-T.; Lin, B.-S.; Chang, Y.-C. Current Development and Application of Anaerobic Glycolytic Enzymes in Urothelial Cancer. Int. J. Mol. Sci. 2021, 22, 10612. https:// doi.org/10.3390/ijms221910612

Academic Editor: Hiroshi Miyamoto

Received: 17 September 2021

Accepted: 27 September 2021

Published: 30 September 2021

Publisher's Note: MDPI stays neutral with regard to jurisdictional claims in published maps and institutional affiliations.

Copyright: () 2021 by the authors. Licensee MDPI, Basel, Switzerland. This article is an open access article distributed under the terms and conditions of the Creative Commons Attribution (CC BY) license (https:// creativecommons.org/licenses/by/ $4.0 /)$.

\begin{abstract}
Urothelial cancer is a malignant tumor with metastatic ability and high mortality. Malignant tumors of the urinary system include upper tract urothelial cancer and bladder cancer. In addition to typical genetic alterations and epigenetic modifications, metabolism-related events also occur in urothelial cancer. This metabolic reprogramming includes aberrant expression levels of genes, metabolites, and associated networks and pathways. In this review, we summarize the dysfunctions of glycolytic enzymes in urothelial cancer and discuss the relevant phenotype and signal transduction. Moreover, we describe potential prognostic factors and risks to the survival of clinical cancer patients. More importantly, based on several available databases, we explore relationships between glycolytic enzymes and genetic changes or drug responses in urothelial cancer cells. Current advances in glycolysis-based inhibitors and their combinations are also discussed. Combining all of the evidence, we indicate their potential value for further research in basic science and clinical applications.
\end{abstract}

Keywords: urothelial cancer; metabolic reprogramming; glycolytic enzymes

\section{Introduction to Urothelial Cancer}

Urothelial cancer occurs in the lower urinary tract, including the bladder and urethra, as well as the upper urinary tract, including the renal pelvis and ureter [1]. Various molecular characteristics and patterns of upper tract urothelial cancer (UTUC) and bladder cancer (BC) have been identified for clinical prediction and diagnosis, respectively. Interestingly, UTUC and BC have different features, leading to different variations. Previous studies have revealed that $\mathrm{BC}$ has a higher mutational burden compared with other common cancer types [2]. This may be partially explained by apolipoprotein B mRNA-editing enzyme, catalytic polypeptide (APOBEC)-mediated mutagenesis. Moreover, several mutated genes and chromatin modifiers (e.g., CREBBP, KMT2C, KMT2D, and KDM6A) have been reported in BC. The main targets include the RTK/Ras/PI3K pathway (FGFR3, ERBB2, HRAS, and PIK3CA) and p53-Rb axis (e.g., TP53, RB1, CCND1, and CDKN2A) (Figure 1).

On the other hand, BC-like incidents do not appear to occur in UTUC. Although the evidence related to UTUC is limited, some events have been described. Compared with BC, CUL3, BCL2L1, and FGFR1 have been recognized as mutation events in UTUC that can potentially be used for its classification (Figure 1). These properties may be due to UTUC-related symptoms, such as Lynch syndrome (which develops in the mesodermderived epithelium) and aberrant aristolochic acid (AA) production [3,4]. HRAS, ERBB2, 
TP53, and RB1 can be used as molecular markers in both types of urothelial cancer because their actions differ between normal tissues and primary tumors [5]. In addition, to comprehensively characterize genetic alterations and various expression panels of UTUC for further experiments, whole-exome sequencing, and RNA sequencing profiles need to be established and integrated through large-scale screening [6,7]. At present, the research is limited, and the number of samples is insufficient, making it difficult to achieve breakthrough progress. In addition to the above-mentioned clinical background, urothelial cancer involves many important factors, such as metabolism.

$$
\text { Bladder Cancer }(n=1823)
$$
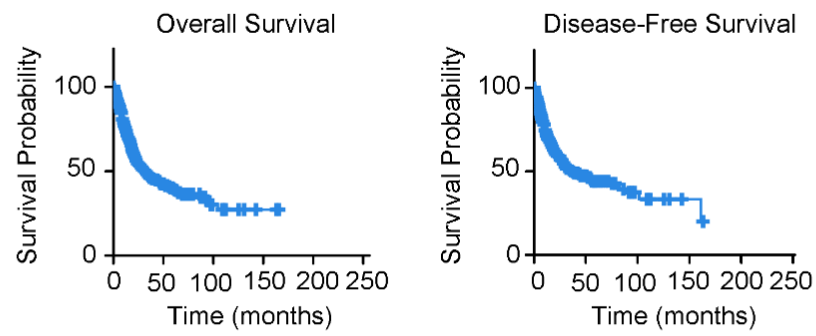

Upper Tract Urothelial Cancer $(n=313)$
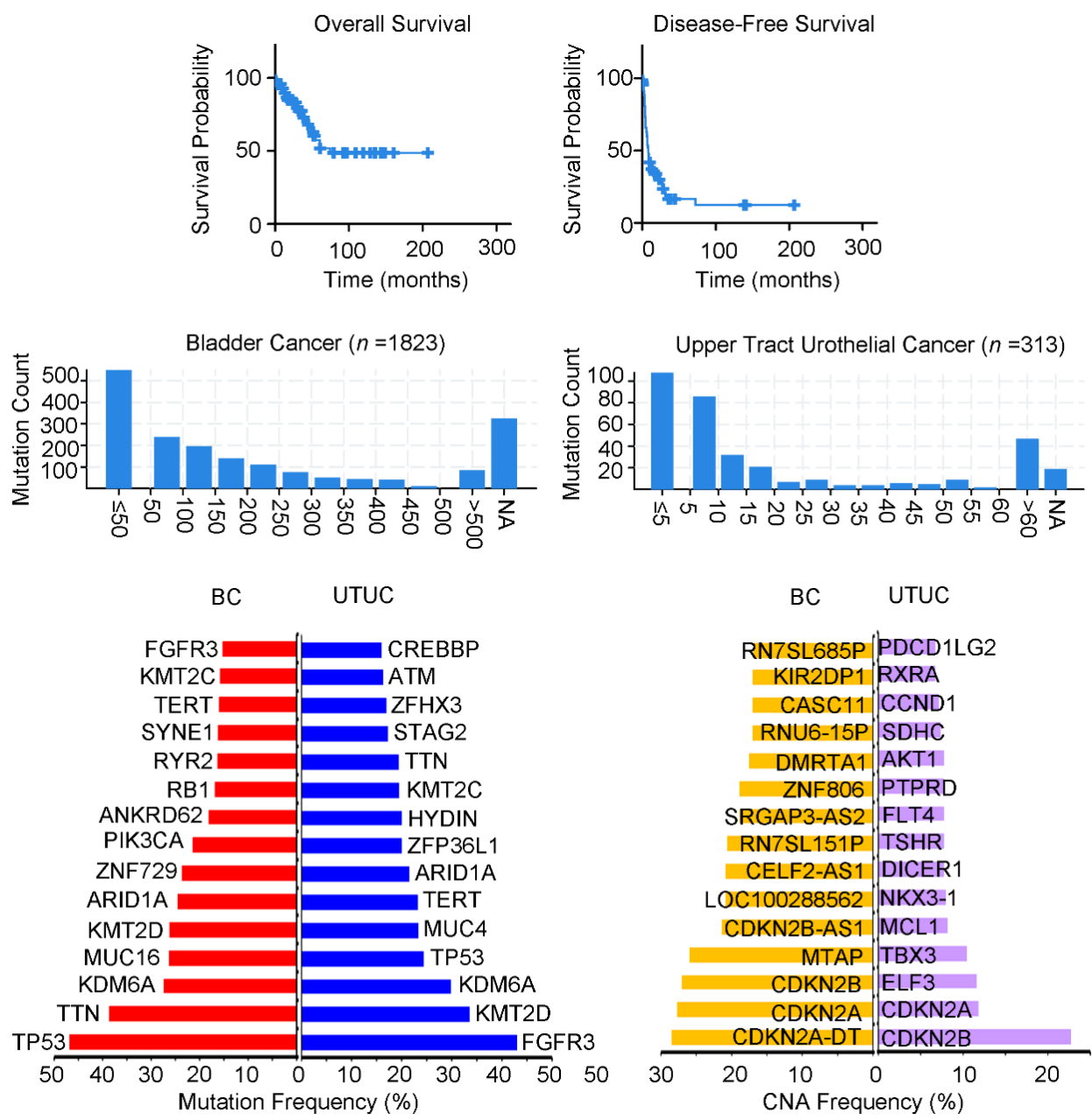

Figure 1. A meta-analysis of BC $(n=1823)$ and UTUC $(n=313)$ cohorts to reveal the survival rates, mutation frequency, and genetic alterations of clinical patients. The overall survival of BC (average 32 months) is worse than UTUC (average 60.79 months), but the disease-free survival rate of UTUC (average 8.5 months) is worse than BC (average 35.3 months). In addition, the TOP15 gene alterations and CNA changes of the two cancers are mostly different, with only a few repetitions but different frequencies. Genetic background and clinical parameters in urothelial cancer. All data were analyzed from the cBioportal website. CNA: Copy number alteration. 


\section{Glycolysis Pathway in UC}

Glycolysis is a typical and sensitive metabolic process that plays a primary role in carbohydrate uptake/utilization, homeostasis, and metabolic reprogramming. According to the physiological function and homeostasis of the internal environment, the direction (from top to bottom or vice versa), efficiency, products, and branches of this pathway can be adjusted at any time. Glycolysis is divided into two main types, namely, aerobic and anaerobic glycolysis, and the reaction depends on the surrounding environment. The glycolytic pathway is responsible for the conversion of glucose to pyruvate and ATP production. Glycolysis first requires glucose transporters (GLUTs) to carry glucose across the cell membrane. This reaction is catalyzed by ten enzymes in the glycolytic pathway: (1) hexokinase (HK); (2) glucose-6-phosphate isomerase (GPI); (3) phosphofructokinase 1 (PFKM); (4) aldolase, aldolase, Fructose-bisphosphate (ALDO); (5) triosephosphate isomerase (TPI1); (6) glyceraldehyde-3-phosphate dehydrogenase (GAPDH); (7) phosphoglycerate kinase (PGK); (8) phosphoglycerate mutase (PGM); (9) enolase, phosphopyruvate hydratase (ENO); and (10) pyruvate kinase (PKM) (Table 1). Only 2 ATP per glucose molecule are synthesized in anaerobic glycolysis, whereas when pyruvate enters mitochondrial respiration, 36 ATP molecules per glucose molecule are produced (aerobic glycolysis). Under aerobic conditions, pyruvate enters the mitochondria, where it is completely oxidized by $\mathrm{O}_{2}$ to $\mathrm{CO}_{2}$ and $\mathrm{H}_{2} \mathrm{O}$, and its chemical energy is mainly stored in the form of ATP. Pyruvate generated by aerobic glycolysis enters the tricarboxylic acid cycle (TCA) or Krebs cycle. In the absence of sufficient oxygen, pyruvate is reduced by NADH through anaerobic glycolysis or fermentation to form various products, including lactate in animals and ethanol in yeasts. On the other hand, in the glycolysis pathway, also called the Embden-Meyerhof-Parnas (EMP) pathway, the starting molecule is glucose, which is a simple and abundant sugar found in carbohydrates that provides energy to most cells. Carbohydrates synthesized in the process of photosynthesis are the main storage molecules of solar energy. After ingestion, complex carbohydrates are enzymatically hydrolyzed into monosaccharides; for example, starch is broken down into $\mathrm{D}(+)$-glucose. The catabolism of glucose is the primary mechanism to meet short-term energy requirements.

In tumorigenesis, cancer cells are activated by aberrant metabolic reprogramming events. These events include changes in oxygen concentration, acidity, and various metabolites. Notably, anaerobic glycolysis is overexpressed in tumor cells and malignant sites. Otto Warburg claimed that anaerobic glycolysis and lactic acid fermentation lead to the proliferation and growth of cancer cells, which is now known as the "Warburg effect". Scientists have successively elucidated the metabolic reprogramming of these processes in various cancer subtypes. For example, urothelial cancer cells are considered "Warburglike", which is characterized by a dependence on aerobic glycolysis and the expression of most glycolytic enzymes [8]. Aerobic glycolysis increases the hypoxic and acidic conditions in the tumor microenvironment and then forms a positive feedback loop with glycolytic enzymes.

\subsection{Upregulation of Glycolysis}

In previous cancer research, scientists have regarded a variety of glycolytic enzymes as housekeeping genes, and their expression levels have been used as loading controls in experiments [9]. However, as we learn more about glycolysis and cancer metabolism, the expression levels of these metabolic genes are also being recognized as variables that drive metabolic events and cancer phenotypes (Figure 2A). Unfortunately, current glycolytic enzymes cannot be fully studies in BC/UTUC. Although abnormal changes have received attention, some observations require more research and samples. Especially for UTUC, there is still a lack of clinical data (e.g., The Cancer Genome Atlas, TCGA) that can be analyzed, so this article is limited and focuses on BC. 


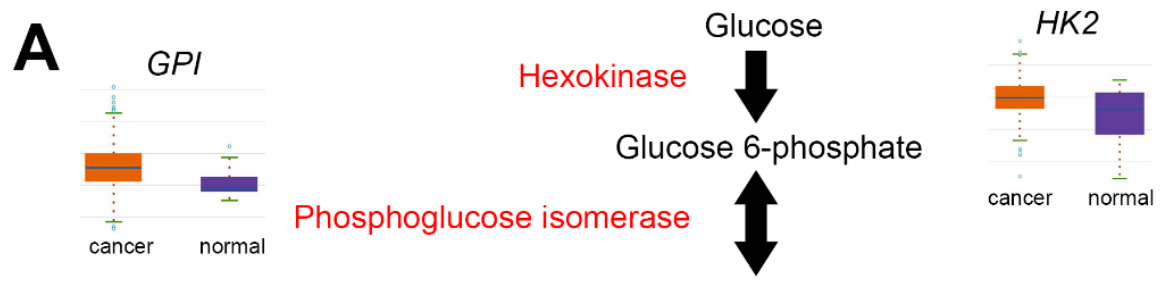

Fructose 6-phosphate

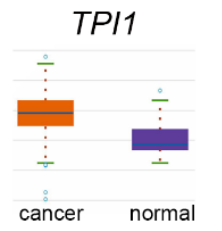

\section{Phosphofructokinase}

Fructose 1,6-biphosphate

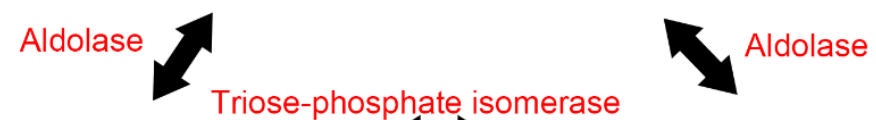

Glyceraldehyde 3-phosphate

Dihydroxiacetone phosphate
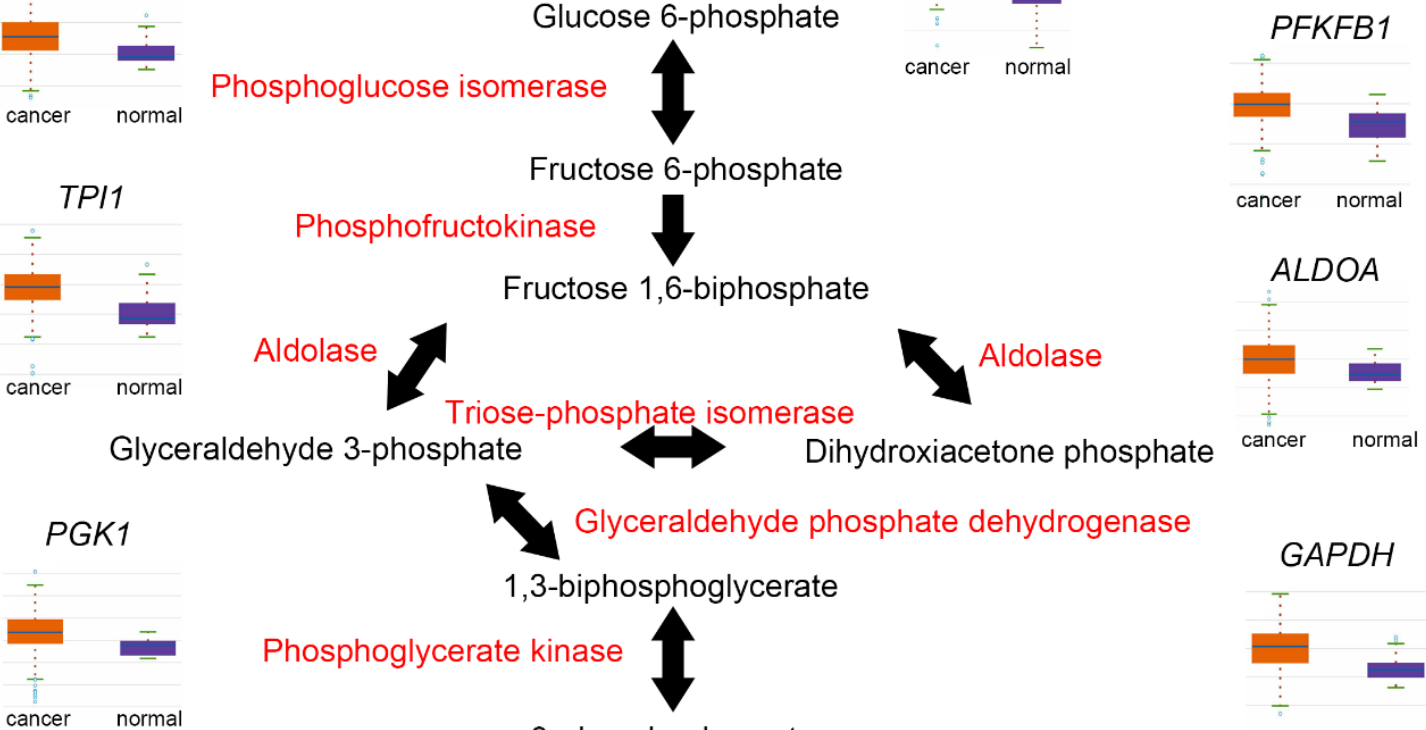

Glyceraldehyde phosphate dehydrogenase

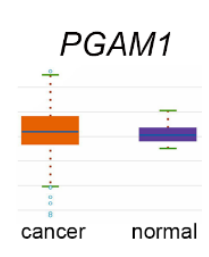

cancer normal

B

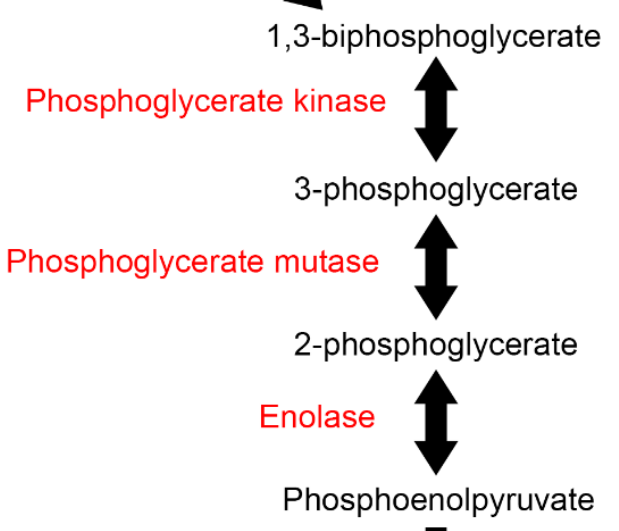

Pyruvate kinase

Pyruvate
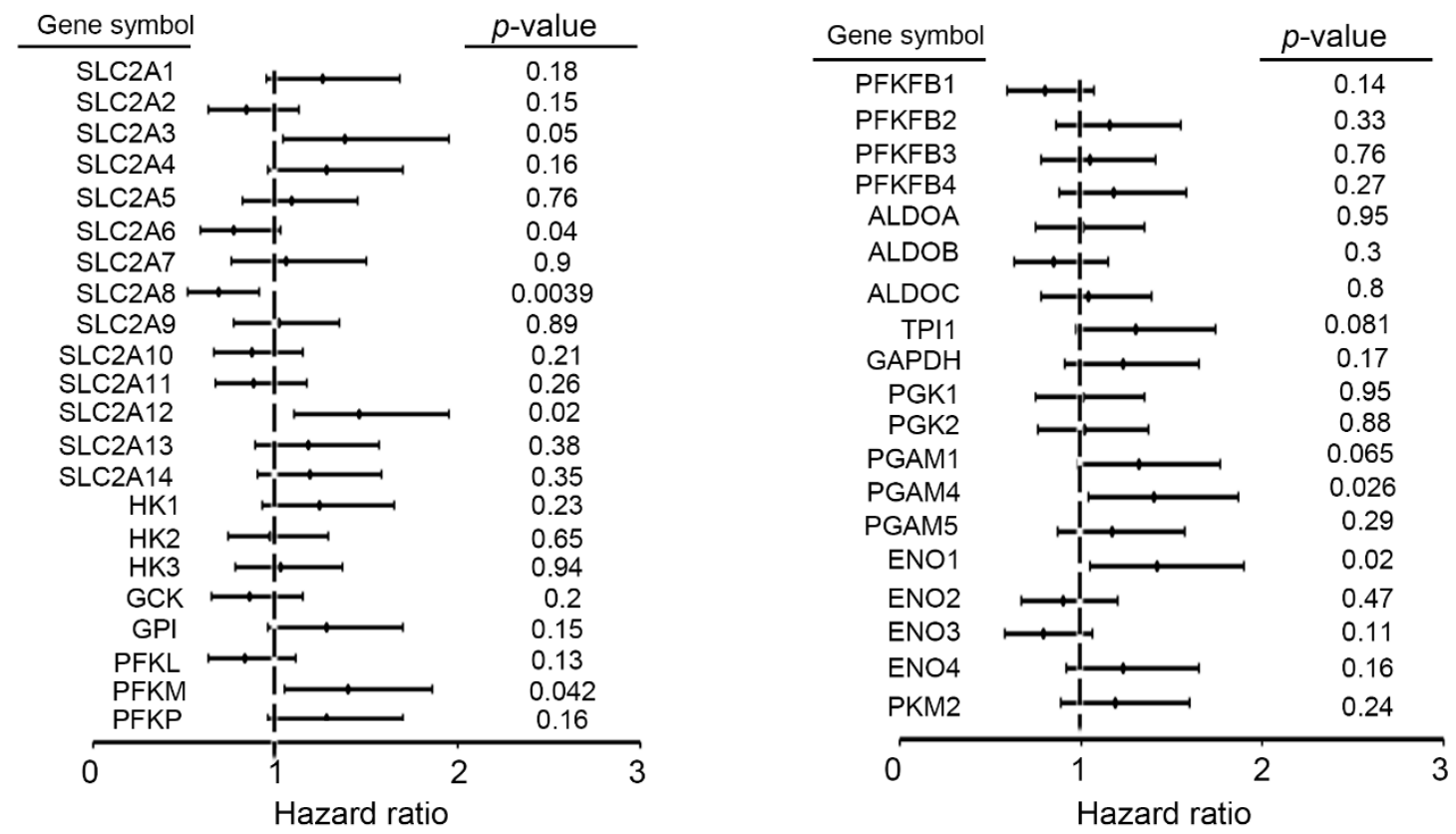

Figure 2. Glycolytic pathway was up-regulated in urothelial cancer. (A) Relative glycolytic enzymes mRNA levels in BC tissues. (B) Hazard ratio, $p$-value, and expression level of each glycolytic enzyme in urothelial cancer. All data were acquired from Kaplan-Meier Plotter, USCS Xena, and ENCORI websites. 


\subsubsection{GLUT}

Increased glucose uptake results in increased glycolytic flux by GLUTs. The GLUT family includes 14 members, and GLUT1 expression has been associated with the grade of malignancy in non-muscle-invasive UC and muscle-invasive UC. In addition, GLUT1 is an independent prognostic marker for survival in BC patients treated with radiotherapy [10]. GLUT3 was also found to be upregulated in BC tumors [11]. Targeting GLUT1 and GLUT3 increases the sensitivity of BC cells to cisplatin and inhibits their proliferation, respectively [12,13].

\subsubsection{HK}

In glycolysis, the first step is the phosphorylation of glucose by HK to form glucose6-phosphate (G6P). In mammalian tissue, HKs have four isoforms: HK I, II, III, and IV (glucokinase) [14-16]. HK II expression maintains the malignant state in cancer, and it needs other protein partners to promote cancer progression, including GLUT, voltagedependent anion channel (VDAC), ATP synthase, and adenine nucleotide translocator [17]. In BC, targeting HK2 suppresses BC progression [18]. Moreover, single-cell sequencing has been used to assess the activity of hexokinase 2 in urine for the non-invasive diagnosis and screening of BC [19].

\subsubsection{GPI}

GPI carries out the second step of catalytic glycolysis. In BC, GPI and other glycolytic enzymes are upregulated during cancer progression [20]. Overexpression of GPI has also been detected in other cancer types [21].

\subsubsection{PFKM}

Phosphofructokinase (PFK), which is a kinase enzyme that transfers a phosphoryl group to Fructose 6-phosphate (F6P) from adenosine triphosphate (ATP), is involved in an important reaction in the glycolysis pathway. Recently, the TCGA program recruited a large number of primary BC tissues and quantified the expression level of each gene through RNA-sequence approaches. Therefore, through the TCGA profiles, most of the PFK family (PFKL, PFKM, PFKP, PFKFB1, PFKFB2, PFKFB3, and PFKFB4) genes are amplified and upregulated in $\mathrm{BC}$ patients. Moreover, treatment with a PFK inhibitor (2,5-anhydro-Dglucitol-6-phosphate) significantly reduced glycolysis and inhibited the cell growth and invasion ability of BC cells [22].

\subsubsection{ALDO}

In the fourth step, aldolase cleaves Fructose 1,6-bisphosphate (F1,6BP) into Glyceraldehyde 3-phosphate (GADP) and Dihydroxyacetone phosphate (DHAP). Aldolase family members are enzymes involved in the fourth step of the glycolysis process and include ALDOA, ALDOB, and ALDOC. Overexpression of ALDOA promotes cell growth, increases the colony formation rate, and enhances invasion ability in BC cells. ALDOA was also observed to modulate the expression of EMT marker, epidermal growth factor receptor (EGFR), mitogen-activated protein kinase (MAPK), and AKT serine/threonine kinase (AKT) phosphorylation levels in BC cells. ALDOA mRNA expression was associated with the stage of cancer and survival in patients with $\mathrm{BC}$ [23].

\subsubsection{TPI}

TPI catalyzes the reversible interconversion between D-glyceraldehyde-3-phosphate (G3P/GA3P) and DHAP [24]. G3P is mainly used as a glycolysis intermediate, and DHAP is a precursor for fatty acid biosynthesis. TPI is regarded as a switch for conversion [25].

\subsubsection{GAPDH}

GAPDH is involved in the glycolysis process and has been regarded as a housekeeping gene in previous studies. A large number of studies have used it as an internal control 
for DNA, RNA, or protein levels [26]. However, GAPDH can regulate glycolysis, gene transcription, apoptosis, and reactive oxygen species (ROS) response [27]. In BC, GAPDH is mentioned because of its abnormal performance, but there is still a lack of relevant research on UTUC.

\subsubsection{PGK}

All members of the PGK family convert 1,3-diphosphoglycerate to 3-phosphoglycerate. Plant genomes contain up to three PGK genes, whereas mammals have two copies and most bacteria have one [28]. Tumor cells have been found to secrete PGK, which reduces the disulfide bonds in serine proteases and plasmin, thereby releasing angiostatin, a tumor vasculature inhibitor, and promoting angiogenesis [29,30]. PGK2 is transcribed from PGK1 via retrotransposition [31]. The gene does not contain introns and is specifically expressed in the testis. Similar to the situation of GAPDH, some glycolytic enzymes (PGK, PGAM, ENO, and PKM) still lack evidence and sufficient profiles to confirm their expression levels in clinical specimens. In contrast, using relatively sufficient BC datasets, we determined that these candidates have signs of overexpression in the tumor (Figure 2A).

\subsubsection{PGAM}

In the eighth step of glycolysis, enzymes in the PGAM family convert 3-phosphoglycerate (3PG) into 2-phosphoglycerate (2PG) through the transfer of a phosphate group. There are five isoforms in the PGAM family, including PGAM1, PGAM2, PGAM4, and PGAM5. The fifth is PGAM3, which is a pseudogene. These PGAMs are similar to other glycolytic enzymes in different organs, and more importantly, their intracellular distribution is different. According to a previous review, PGAM1 and PGAM4 are located in the nucleoplasm, PGAM2 is located in the cytosol, and PGAM5 is located in the mitochondria [32]. Through the comparison of the human protein atlas website, PGAM1 is mainly expressed in BC, while PGAM5 is upregulated in UTUC. Such differences still need to rely on further research to identify and clarify.

\subsubsection{ENO}

Enolase catalyzes the conversion of 2-phosphoglycerate to phosphoenolpyruvate (PEP), which consists of three family members: $\alpha$-enolase (ENO1), $\gamma$-enolase (ENO2), and $\beta$ enolase (ENO3). Similar to other glycolytic enzymes, the enolase family behaves differently in most tissues. Unlike ENO2 (neuronal cells) and ENO3 (muscles), ENO1 has been found to be overexpressed in many cancers [33]. In various solid tumors, ENO1 has also been reported to increase glycolytic turnover and promote tumorigenesis. Moreover, ENO1 can divide a full-length canonical $\alpha$-enolase into a truncated version, called Myc promoterbinding protein 1 (MBP1) [34]. In addition, their prognostic/diagnostic value in cancer has been confirmed [35]. In urothelial cancer, high expression of ENO1 is positively correlated with poor prognosis, ENO2 is negatively correlated, and ENO3 has no performance in tissue slides [36,37].

\subsubsection{PKM}

Pyruvate Kinase isozymes M1/M2 (PKM1/PKM2) are responsible for the conversion of phosphoenolpyruvate (PEP) to pyruvate during glycolysis [38]. The family is composed of PKM1 and PKM2, which are differentially distributed, localized, and modified in cells. PKM1 is ubiquitously expressed in organs, and PKM2 is upregulated in tumorigenesis in various cancers, including urothelial cancer [39]. They consist of 12 exons and 11 introns, but changes in splicing lead to different protein molecular weights and structures [40]. Although some studies mention that PKM1-PKM2 undergoes a transition or shift in tumorigenesis, this remains to be thoroughly investigated. More research is needed to detect the consequences of PKM2 overexpression and activation [41,42]. Two isomeric forms (dimers and tetramers) of PKM2 have been found to be important factors in glycolysis [43]. The dimeric form of PKM2 is involved in fermentation to produce lactic acid, especially in can- 
cer cells, while the tetrameric form continues to activate aerobic glycolysis and subsequent oxidative phosphorylation. These two forms correspond to the tissue type, PKM enzyme activity, and local tumor environment [44].

Table 1. Enzymes of glycolysis pathway.

\begin{tabular}{|c|c|c|c|}
\hline Enzyme & Gene & Function in Cancer & Reference \\
\hline Hexokinase & HK & cancer progression & [14] \\
\hline Glucose-6-Phosphate Isomerase & GPI (PGI) & cancer progression & [20] \\
\hline Phosphofructokinase 1 & PFKM & cell growth and invasion ability & [15] \\
\hline Aldolase, Fructose-Bisphosphate A & ALDOA & cell growth, colony formation rate, and invasion ability & [16] \\
\hline Triosephosphate Isomerase 1 & TPI1 & NA & \\
\hline $\begin{array}{l}\text { Glyceraldehyde-3-Phosphate } \\
\text { Dehydrogenase }\end{array}$ & GAPDH & gene transcription, apoptosis, and ROS response & [18] \\
\hline Phosphoglycerate kinase & PGK & angiogenesis & {$[29,30]$} \\
\hline Phosphoglycerate mutase & PGM & NA & \\
\hline Enolase, phosphopyruvate hydratase & ENO & $\begin{array}{c}\text { prognostic/diagnostic value in cancer has been } \\
\text { confirmed }\end{array}$ & [35] \\
\hline Pyruvate kinase & PKM2 & tumorigenesis & {$[29,30]$} \\
\hline
\end{tabular}

\subsection{Metabolic Reprogramming, Tumor Microenvironment, and Consequences}

Aberrant glycolysis not only affects glucose-related products and intermediates but also triggers a series of critical cascade reactions, particularly metabolic reprogramming, activation of oncogenic pathways, and the promotion of various cancer phenotypes. Metabolic reprogramming occurs in the tumor microenvironment (TME) and influences the survival and function of tumor and immune cells. Their influence is not limited to changes in glucose. High levels of glucose cause excessive lactate formation and secretion into the extracellular space. The accumulation of extracellular lactate may create a TME that is beneficial for the malignant phenotype in cancer cells, including migration and angiogenesis, and it may also impair the immune system, allowing the tumor to evade immune detection [45]. Wang et al. observed that glycolysis-related genes (LDHA, TPI, and PGK1) and glutaminolysis-related genes (SLC1A5, GLS, and GLUD1) were elevated in $\mathrm{BC}$ and the surrounding $\mathrm{T}$ cells, reflecting the immune response. On the contrary, the dependence on oxidative phosphorylation (OXPHOs) is greatly reduced [46].

Afonso et al. described the relationship between glycolysis and immunotherapy. They claimed that competitive glucose metabolism is the goal of promoting immunotherapy for $\mathrm{BC}$ [47]. As mentioned above, the metabolic phenotype of $\mathrm{BC}$ cells is heterogeneous and differs from its counterparts in normal tissues because cancer cells have a strong demand for nutrients, especially glucose. There is an overlapping metabolic phenotype between cancer cells and activated $\mathrm{T}$ cells, leading to metabolic competition, limiting the availability of nutrients, increasing microenvironmental acidosis, and impairing the immune function of T cells. Numerous inhibitors of glucose metabolism have been shown to be effective in eliminating cancer cells that overexpress glycolysis-related targets, including silibinin, 2-deoxy-D-glucose, PFK158, gossypol, dichloroacetate, quercetin, metformin, and phenformin [48-52]. Integrating the targeting of BC metabolism into immunotherapy design seems to be a rational approach to improve the therapeutic efficacy of immune checkpoint inhibitors (Atezolizumab, Nivolumab, Duvalumab, Avelumab, and Pembrolizumab) [53-59].

\section{Potential Signaling Pathways and Key Drivers of Glycolytic Enzymes}

Glycolysis interacts with several carcinogenic pathways. These signals drive the expression levels of glycolytic enzymes through potential transcription factors, RNA interference, and modifications, forming a positive feedback loop. 


\subsection{Signaling Pathway}

The Phosphoinositide 3-kinase (PI3K)/protein kinase B (AKT)/mammalian target of rapamycin (mTOR) pathway is a common metabolic pathway that induces and regulates the Warburg effect $[60,61]$. In BC, this axis drives the increase in the glycolysis rate and is associated with the overexpression of several core glycolysis-related genes, such as GLUT1, HK1/2, and LDHA [8,62-64].

In addition, HLA-F locus adjacent transcript 10 (FAT10) promotes cell growth and mediates HK2 expression through the EGFR/AKT pathway in BC cells. It was also shown that the upregulated expression of HK2 correlated with FAT10 in BC patients [65]. On the other hand, PKM2 modulated the expression of SREBP-1c via the AKT/mTOR signaling pathway, which suppressed the transcription of fatty acid synthase (FASN, a major lipogenic gene), leading to reduced tumor growth. The PKM2 inhibitor (shikonin) was also shown to reduce cell proliferation and colony-forming abilities in a BC cell line [66].

\subsection{Regulators \\ 3.2.1. HIF- $1 \alpha$}

Hypoxia-inducible factor 1 alpha (HIF- $1 \alpha$ ) is one of the most well-known transcription factors, and its function is closely related to its role in metabolic reprogramming. Modification of HIF- $1 \alpha$ in tumorigenesis has been identified in many studies. For example, Zhao et al. investigated the relationship between steroid receptor coactivator-3 (SRC-3) and HIF- $1 \alpha$ in BC. They reported that SRC-3 can target the promoter region of HIF- $1 \alpha$ and, as a result, accelerate the development of hypoxic conditions and anaerobic glycolysis through HIF- $1 \alpha$ and its downstream target glycolytic enzymes [67]. Similarly, JMJD1A is a histone demethylase that specifically demethylates H3K9me 1/2. In a BC model, JMJD1A cooperated with HIF- $1 \alpha$ and then upregulated various downstream genes, including some glycolytic enzymes, such as HK2, LDHA, and PGK1 [68].

HIF- $1 \alpha$ is a well-known transcription factor and is activated in tumorigenesis. A large amount of research has validated that HIF- $1 \alpha$ is stabilized, extended, and then translocated to the nucleus, where it affects downstream pathways. In addition to its ability to directly target the hypoxia response element (HRE) in many glycolytic enzymes, HIF- $1 \alpha$ also participates in microRNA- and RNA-binding mechanisms to regulate glycolytic enzyme RNA levels [69-71]. Wang confirmed that Aly/REF export factor (ALYREF) enhances RNA stability in the PKM2 $3^{\prime}$ UTR region, and the HIF-1 $\alpha$ / ALYREF/PKM2 axis is formed to regulate glycolysis and proliferation in BC [72].

\subsubsection{TP53}

TP53 is a well-known tumor suppressor, but it frequently undergoes mutation in tumorigenesis in various cancers. Once the loss of function of TP53 occurs, DNA damage, apoptosis, and repair mechanisms are affected [73,74]. At the same time, TP53 acts as a transcription factor that directly binds to the E3 ubiquitin ligase, which facilitates the degradation and stability of nuclear proteins [75].

\subsubsection{Insulin}

Insulin acts as an additional factor and amplifies the signal transduction of glycolysis. It has been observed that certain hormones/growth factors favor insulin secretion in some cancer types and increase the risk of cancer development. In particular, when insulin is sufficient, GLUT4 acts as an insulin-responsive glucose transporter that continues to initiate the glycolysis mechanism. Although insulin concentration may not be a major risk factor for BC [76], it is still important to mention that high glucose $(55 \mathrm{mM})$ and insulin $(50 \mathrm{U})$ can promote the cell cycle progression and oncogenic signaling activation of bladder epithelial cells [77]. 


\subsection{Modifications}

In addition to genetic alterations that affect RNA expression, epigenetic modification is also an important mechanism for regulating expression levels. Downregulation of miR$125 b-5 p$ in BC tissues and cancer cell lines and low miR-125b-5p expression were associated with decreased 5-year survival in patients. Furthermore, targeting HK2 with miR-125b-5p inhibited BC cell progression [18].

Hypomethylation of the PGK1 promoter has been observed in several cancer subtypes. Through TCGA pan-cancer profiles, Shao et al. described the PGK1 promoter hypomethylation status in bladder cancer and others [78]. Although their study did not confirm that the hypomethylation status or expression level of PGK1 can be used as an indicator of different stages, they validated that PGK1-related events can serve as independent prognostic factors and are associated with poor survival. In addition, they also reported that the S203 site of PGK1 can be phosphorylated by ERK at the tumor site [79].

\subsection{Protein-Protein Interactions}

The non-enzymatic functions of many glycolytic enzymes have been identified in diseases and cancers [80]. These mechanisms can occur through direct protein-protein interactions rather than metabolites and metabolism-related pathways. These changes do not replace regular functions but support the mechanism of disease occurrence. For example, ALDOA- $\gamma$-actin and PGAM1-ACTA2 regulate the cell cytoskeleton and mobility, and PGK1-HTATSF1 promotes metastasis [81-83]. Researchers are working to produce accurate protein crystal structures and identify high-affinity binding partners of other glycolytic enzymes. Liu et al. focused on the C-terminal region of PGAM1 and validated the key residues in the PGAM catalytic cycle [84]. Zhai's team and Butera's group discovered that nuclear TP53-GAPDH forms a complex that supports glycolysis and drug resistance [85,86]. GPI is genetically identical to autocrine motility factor (AMF), a $55 \mathrm{kDa}$ extracellular cytokine that can accelerate the migration of cancer cells [87].

\subsection{Translocations}

Several enzymes have been explored to characterize their translocation and their effects on comprehensive phenotypes in cancer. (1) When insulin-responsive glucose transporter, also known as GLUT4, receives the insulin signal, it is moved from GLUT4 storage vesicles to the cell membrane to increase glycolytic transport activity [88]. (2) Responding to the metabolic stress in cancer cells, HK2 is transferred to the outer mitochondrial membrane and improves metabolic capacity [89]. (3) The subcellular distribution of ALDOA is associated with survival signals and proliferation, and the nuclear localization of ALDOA responds to metabolic conditions [90]. (4) GAPDH has been confirmed to undergo nuclear translocation, let can induce apoptosis, and AKT2 can inhibit these events [91]. (5) Phosphorylation of PGK1 (S203) leads to mitochondrial translocation, which then decreases the TCA cycle and ROS production and increases pyruvate and lactate [79]. (6) A different form of ENO1, $\alpha$-enolase, is localized in the cytoplasm, but MBP1 is preferentially trafficked to the nucleus for further repression of the transitional activity of c-Myc [92]. (7) PKM2 can exist as a tetramer to execute its enzyme function or as a dimer to carry out its non-glycolytic function in the nucleus [34]. Although these issues may be rarely mentioned and investigated in urothelial cancer, they are still important topics that need further analysis.

\subsection{Non-Coding RNAs}

In each cancer type, long non-coding RNAs are also involved in regulating the activity and metabolic effects of glycolytic enzymes [93]. Duan et al. observed that the lncRNA known as cancer susceptibility candidate 8 (CASC 8 ) is reduced in the advanced stage of BC. Loss of function of CASC8 interferes with the binding of FGFR1, which in turn interferes with the phosphorylation state of LDHA [94]. On the other hand, urothelial cancer-associated 1 (UCA1) lncRNA upregulates HK2 expression and promotes glycolysis 
through the mTOR-STAT3 axis [95]. Similarly, some studies indicate that miR-143 mediates mTOR activity and HK2 expression [96].

Using two-dimensional polyacrylamide gel electrophoresis (2-DE)-based proteomics approaches, Peng et al. observed that PGAM1 was significantly upregulated in BC related to histological grade and poor differentiation. Dyrskjot and his group also claimed that miR-483-3p can target PGAM1 and PGAM4 $[97,98]$. In BC, miR-26a-5p and miR-26b-5p were determined to have tumor-suppressive effects, such as inhibiting cell aggressiveness, and glycolysis was proposed as one of the canonical pathways with potential involvement, along with downstream targets, such as HK2, ENO3, PGAM1, and PGAM4 [99]. Moreover, miR-21 was reported to reduce aerobic glycolysis in a BC cell line by increasing PTEN expression, decreasing AKT phosphorylation status, and inactivating mTOR. Furthermore, regulation of several glycolytic genes (GLUT1, GLUT3, HK1, HK2, LDHA, LDHB, and PKM) and events (glucose uptake and lactate production) was observed [100].

\subsection{Others}

Interestingly, Juwita et al. claimed that in two BC cell lines (RT4 and MGH), GAPDH was induced by Bacillus Calmette-Guerin, which is the standard therapy for non-muscleinvasive BC [101]. Although the specific mechanisms are still unclear, GAPDH is no longer suitable as a housekeeping gene for $\mathrm{BC}$, as is in the case of gastric cancer [102]. According to Wu et al.'s report, esculetin can inhibit glycolysis by binding GPI and PGK2 in cancer cells, but the detailed mechanism remains to be explored [103].

\section{Various Effects of Glycolytic Enzymes on Phenotypes of UC}

\subsection{Proliferation}

The overexpression of most glycolytic enzymes has been revealed to enhance the proliferation ability of cancer cells by accelerating the efficiency and yield of glycolysis. In particular, the PI3K/Akt signaling pathway is a typical example of metabolic reprogramming/carcinogenic signal crosstalk. However, there are not many reports on the detailed molecular mechanism, Ji et al. reported that ENO1 promotes the growth and proliferation of BC cells through $\beta$-catenin and its downstream target cyclin D1 [104]. Xie et al. investigated the alternative splicing of PKM by PTBP1 regulated in BC. They confirmed that PKM2 is the essential factor in cancer proliferation. Although PTBP1 has been deprived, PKM2 remains and promotes the proliferation of BC [105].

\subsection{Metastasis}

Yan et al. reported that RNA-binding motif protein X-linked (RBMX) regulated cell proliferation, colony formation, and metastatic ability in metastatic BC [106]. They observed that RBMX competitively inhibited the combination of the RGG motif in hnRNP A1 and the sequence flanking PKM exon 9, leading to the formation of lower PKM2 and higher PKM1 levels, which attenuated the tumorigenicity and progression of metastatic BC. On the other hand, $\mathrm{Li}$ et al. observed that ALDOA was partially positively associated with the EMT phenotype to regulate the invasion of $\mathrm{BC}$ cells. Among non-invasive or invasive $\mathrm{BC}$ cells, EMT has been identified as an important issue and reflects cancer metastasis. ALDOA is associated with EGF/EGFR, MAPK/ERK, and PI3K/Akt pathways to reduce E-cadherin activity. At the same time, $\mathrm{N}$-cadherin, vimentin, and mesenchymal markers were upregulated [23].

\subsection{Drug Resistance}

In urothelial cancer, platinum-based drugs such as cisplatin are included in the standard regimens for clinical patients. However, drug resistance often occurs in clinical cases and cell lines. Recently, T24 cells resistant to cisplatin $(40 \mu \mathrm{M})(\mathrm{T} 24 \mathrm{CDDPR})$ were established and compared with cisplatin-naïve (T24) cells through two-dimensional gel electrophoresis and LC-MASS. PGK1 was 1 of 25 differently overexpressed proteins ( $>1.5-$ fold change) in T24CDDPR cells compared with T24 cells [107]. Wang's group claimed 
that, in addition to platinum-based compounds, shikonin can specifically bind to PKM2, but PKM1 does not. This interaction mechanism reduces the resistance of BC cells to cisplatin. The combined use of cisplatin and shikonin has a synergistic effect, increasing the rate of apoptosis and autophagy of cell lines. Moreover, they observed this regulation through the PKM2 enzyme-independent pathway, and therefore, it did not induce metabolic reprogramming [108].

\section{Prognostic and Diagnostic Value of Glycolytic Enzymes for UC}

For urothelial cancer, urine is a reliable source for the non-invasive detection of appropriate biomarkers. Various studies have analyzed changes in the urine of cancer patients compared with healthy subjects. Through high-throughput screening and an omics approach, several glycolytic enzymes were identified in these events. Liu et al. observed that PKM2 (0-1000 U/mL, $n=50)$ was highly expressed in the urine of cancer patients compared with the normal group $(0 \mathrm{U} / \mathrm{mL}, n=10)$. After evaluation, they determined that the ROC curve was 0.9 , with $82 \%$ sensitivity and $100 \%$ specificity for BC [109]. In addition, there have been many studies on the prognosis/diagnosis of PKM2 in urothelial cancer, provided that PKM2 expression levels in the tumor and normal tissue can be defined. Physiological mechanisms such as localization and phosphorylation are easy to detect. Combined with existing clinicopathological factors, PKM2 has been revealed in various aspects of tumor pathology.

On the other hand, using 2-DE and MALDI-mass spectrometry, Zhou et al. reported that PKM2 is also overexpressed in urothelial cancer [110]. From low-grade papillary urothelial cancer to high-grade invasive urothelial cancer, the expression level of PKM2 increased, and translocation from the cytoplasm to the nuclear region occurred. In addition, the phosphorylation status of PKM2 increased at the same time. There was no significant change in PKM1 in the urothelial cancer cell panel. Huang et al. demonstrated that the RNA and protein levels of PKM2 are upregulated in BC. They collected 215 cases and calculated the relationship between PKM2 and clinical parameters. PKM2 expression was correlated with poor disease-free survival and served as an independent prognostic factor in multivariate analysis $(\mathrm{HR}=3.5, p<0.001)$ [111].

However, Lu et al. confirmed that the PGK1 protein level has several connections with clinical parameters of gallbladder cancer (GBC). In their GBC cohort $(n=95)$, the expression of PGK1 in GBC was significantly reduced compared with non-cancerous gallbladder mucosa. Through Kaplan-Meier analysis and univariate/multivariate approaches, PGK1 protein was correlated with a good survival rate and independent value of GBC. Moreover, PGK1 was stronger in GBC than TNM or had a comprehensive synergistic effect with TNM [112]. Most glycolytic genes were overexpressed and were associated with poor survival rates. PFKFB4 has been suggested as a potentially suitable prognostic marker in non-muscle-invasive $\mathrm{BC}(\mathrm{HR}=2.026(1.177-3.488), p=0.011)$ [113]. The prognostic value of GLUT1 has been revealed in BC, especially at a low stage and low grade [114,115]. These findings indicate that the upregulation of glycolytic enzymes is not a conclusion and consequence and can be further used to formulate clinical strategies and monitoring targets (Figure 2).

\section{Omics Datasets Available in UC}

To analyze the copy number alteration (CNA) events, mutation status, or expression level of each glycolytic enzyme in BC, multi-omics data have been established and updated over the past decade. These clinical cases have been collected and analyzed through large-scale screening by research institutions. From online websites and tools, normalized configuration files can be easily mined to obtain relevant data (Table 2). These data have been generated by microarray chips, RNA sequencing, genomics, epigenetic alterations, and proteomics. In addition to the above-mentioned clinical population, databases have also been established based on cell/animal experiments. These profiles can be divided into 
several types: (1) built models of overexpression or knockdown, (2) comparison of drug or carcinogen exposure, and (3) analysis based on specific phenotypes or signals.

As a practical application, Kim et al. detected FGFR3 alterations and analyzed the immune response in metastatic urothelial cancer (GSE176307). Phung et al. and Therkilden et al. used formalin-fixed paraffin-embedded tissue from a single Lynch Syndrome patient (GSE146670 and GSE104922) and studied changes across time, tissues, and space [3]. Sjodahl made some array chips to examine differentially expressed molecules in the early stage of advanced urothelial cancer (GSE128959) [116]. There are also several omics data profiles based on drug resistance design, such as GSE122358, GSE112973 [117], GSE98096 [118], GSE92651 [119], and GSE58624 [120].

Lee et al. identified the BC cell line J82 and its derived xenograft tumors, MDXC1 (GSE156348) [121]. In this study, they found that some tyrosine kinases may be potential treatment strategies. Lee et al. and Chen et al. used an RNA sequencing approach to distinguish normal/tumor pairs in patients with urothelial cancer (GSE159824 and GSE133624) [122,123]. Many scientists have generated their data from patient-derived xenografts (PDXs) and organoids (GSE155007 and GSE134292) [124]. Such research also includes GSE77952 [125], GSE125286, GSE111933 [126], GSE68020, GSE129441 [127], and GSE103990 [128].

Zavadil's group performed a series of dose/time-dependent aristolochic acid exposure in patients and normal tissues. In these datasets, mRNA, microRNA, and urine sample data were included (GSE166716, 166,907, 166,909, and 166,912). Similarly, Jou et al. analyzed cyproheptadine and epigenetic modification in urothelial cancer (GSE160703) [129]. Additional studies have built models by adding medications, including GSE90023 [130], GSE45385, GSE74478 [131], GSE102170 [132], and GSE103928. These datasets may not be designed for metabolic changes or events, but comprehensive physical data can bring us closer to the clinical perspective and can increase our understanding of the dynamics of all metabolism-related genes and pathways, which are more useful in practice.

Table 2. Available studies for visualization and analysis of urothelial cancer (bladder/upper tract). All data and their corresponding clinical parameters were obtained through whole-exome or RNA sequencing approaches. These clinical cohorts were collected from the cBioportal website and previous studies. Please refer to the original references or cBioportal website for the definition of subtypes.

\begin{tabular}{cccc}
\hline Source & Year & Cases & Reference \\
\hline MSK/TCGA & \multicolumn{2}{c}{ Bladder cancer (BC) } & NA \\
MSKCC & 2020 & 476 & {$[133]$} \\
MSKCC & 2014 & 109 & {$[134]$} \\
MSKCC & 2013 & 97 & {$[135]$} \\
TCGA & 2016 & 34 & {$[2]$} \\
BGI & 2017 & 413 & {$[136]$} \\
DFCI/MSKCC & 2013 & 99 & {$[137]$} \\
TCGA & 2014 & 50 & NA \\
TCGA & 2016 & 413 & {$[138]$} \\
TCGA & 2014 & 131 & {$[139-142]$} \\
MSK & 2018 & 411 & {$[143]$} \\
Cornell/Trento & 2017 & 105 & {$[144]$} \\
MSK & 2016 & 72 & {$[145]$} \\
Cornell/Baylor/MDACC & 2015 & 85 & {$[7]$} \\
IGBMC & 2019 & 47 & {$[146]$} \\
MSK & 2021 & 30 & {$[147]$} \\
MSK & 2020 & 119 & {$[147]$} \\
\hline
\end{tabular}

MSKCC: Memorial Sloan Kettering Cancer Center; TCGA: The Cancer Genome Atlas; IGBMC: Institute of Genetics and of Molecular and Cellular Biology; BGI: Beijing Genomics Institute. 


\section{Current Combinations and Clinical Trials Based on Glycolytic Inhibitors Potential Compounds/Strategies}

For targeted glycolytic enzymes and metabolic reprogramming in tumorigenesis, reordering or interfering with intermediate production may have a dramatic impact. Previous studies have found that knocking down PGAM1 to accumulate 3-PG and reduce 2-PG production could inhibit glycolysis and the oxidative pentose phosphate pathway in BC cells [148]. Apoptosis and a decreased proliferation rate have also been induced in cancer cells in vitro and in vivo. In addition, HKB99, an allosteric inhibitor of PGAM1, was developed to block the interaction between PGAM1 and ACTA2 through structure-based optimization [82]. In this study, they compared the lead compound PGMI-004A and several candidate compounds (MJE3, EGCG, and 12r) with HKB99 and found that HKB99 had the most significant effect on lung cancer cells [149-151]. Although there is no clear evidence for HKB99 in urothelial cancer, some references indicate that it can be applied and tested.

In the past, inhibitors have been developed to block or interfere with enzymes involved in glycolysis. Several inhibitors are also used in urothelial cancer (Table 3). Choi summarized the anti-cancer effect of phloretin [2', $4^{\prime}, 6^{\prime}$-trihydroxyphenyl]-propiophenone]. In a BC study, phloretin was found to inhibit glucose uptake by reducing the expression of glucose transporters $[152,153]$. Quercetin has been identified as having cytotoxic and genotoxic effects on human BC cells [154], and it can induce BC apoptosis through the AMPK axis [155]. WZB117 uses non-specific inhibition to reduce the transport of glucose transporters, thereby slowing the rate of glycolysis. According to reports, ritonavir and indinavir produce similar trends to WZB117 [156]. Some drugs are used alone or in combination with existing chemotherapeutics to improve their efficiency against glycolytic enzymes. These candidate drugs include 3-bromopyruvate, 2-deoxyglucose, 3PO, 2-phospho-D-glyceric acid, sodium fluoride, and benzo[a]pyrene [48,157-159].

Table 3. Development phase of glycolytic enzyme compounds in UC and their pre-clinical or clinical effects.

\begin{tabular}{cccc}
\hline Inhibitor & Targets & Reference & Application in UC \\
\hline Phloretin & GLUTs & {$[160,161]$} & {$[162]$} \\
Quercetin & GLUT1/PKM2/LDHA & {$[161,163]$} & {$[154,155]$} \\
STF31 & GLUT1 & {$[48]$} \\
WZB117 & GLUT1 & {$[164]$} & {$[48,157]$} \\
3-Bromopyruvate & HK & {$[161]$} & {$[48]$} \\
2-Deoxyglucose & HK & NA \\
D-fructose-6-phate & GPI & {$[165]$} & {$[48]$} \\
3PO & PFKFB & {$[166]$} & NA \\
4-Deoxy-D-glucose & Aldolase & {$[168]$} & {$[158]$} \\
2-phospho-D-glyceric acid & TPI & NA \\
Iodoacetate & GAPDH & NA \\
Tubercidin & PGK & {$[81]$} & NA \\
Mellitic acid & PGAM & {$[169]$} & {$[173]$} \\
Sodium fluoride & ENO & {$[171]$} & NA \\
Shikonin & ENO & {$[172]$} & {$[176,177]$} \\
3-aminoenolphate & PKM2 & {$[169]$} & NA \\
Oxamic acid & PKM2 & {$[174,175]$} & NA \\
NHI-1 & LDH & {$[167]$} & NA \\
Benzo[a]pyrene & LDHA & {$[178]$} & {$[159]$} \\
\hline
\end{tabular}

The role of certain compounds is to alter the processes of metabolic reprogramming and several branches of production. The consequence of these drugs is not the regulated expression of a single gene but a large-scale metabolic event. This also means that the use of the above drugs has limitations and involves physiological considerations. In addition, some valuable potential inhibitors (D-fructose-6-phosphate, 4-deoxy-D-glucose, iodoacetate, tubercidin, mellitic acid, 3-aminoenolpyruvate 2-phosphate, pyridoxal-5'- 
phosphate, oxamic acid, and NHI-1) can be administered to cells and animal models for further studies of urothelial cancer.

\section{Future Prospects}

In this article, we describe the pathways and events of glycolytic enzymes involved in urothelial cancer. Although there are many studies on multiple genes in other cancer types, UTUC and BC are characterized by specific genetic alterations and features. This does not mean that previous studies on our topic can necessarily be replicated, and more research is needed to confirm their results and clarify their limitations.

Through the large-scale screening of urothelial cancer and the establishment of omics databases, it has been reported that the RNA or protein levels of various glycolytic enzymes may be abnormally expressed, and the enzymes may be dysfunctional. However, with the confirmation of genetic modification events and the development of specialized inhibitors, glycolytic enzymes need to be reevaluated not as independent events but to discover their additional clinical value. Previously, an FGFR inhibitor, Debio 1347 (CH5183284), was found to be a possible resistance mechanism [180]. The follow-ups-Infigratinib, Erdafitinib, Pemigatinib - are specially designed for FGFR members and have been applied to urothelial cancer [181]. If scientists determine the relationship between glycolytic enzymes and typical genetic changes, it may increase the response and synergistic effect in clinical practice.

In addition, past studies have recognized that glycolytic enzyme inhibitors can have strong side effects and may cause irreversible catalytic processes in the human body. Moreover, cancer cells have alternative feedback loops/branches to preserve specific deficient nutrients. There are many effects of glucose deprivation in cancer cells, but cells can be converted to use glutamate to maintain their behavior and function. Therefore, some glycolytic enzyme-related inhibitors have failed in animal models or clinical trials. On the contrary, new small-molecule drugs or peptides will be based on protein-protein interactions, and whether enzyme functions and metabolic events are affected will need to be carefully examined. These research directions will determine the application and translational medicine potential of glycolytic enzymes in urothelial cancer.

Author Contributions: Conceptualization, all authors; methodology, Y.-F.Y., B.-S.L. and Y.-C.C.; software, B.-S.L. and Y.-C.C.; resources, H.-W.C. and W.-T.K.; data curation, Y.-F.Y., H.-W.C., W.-T.K.; writing-original draft preparation, Y.-F.Y. and Y.-C.C.; writing—review and editing, all authors; visualization, B.-S.L. and Y.-C.C.; supervision, Y.-C.C.; project administration, Y.-C.C.; funding acquisition, Y.-F.Y. and Y.-C.C. All authors have read and agreed to the published version of the manuscript.

Funding: This study was supported by grants from Kaohsiung Veterans General Hospital, Taiwan (grant number KSVGH110-144) and Ministry of Science and Technology (MOST 110-2314-B-075B009-MY3 to Yi-Fang Yang and MOST 110-2320-B-010-008-MY2 to Yu-Chan Chang).

Conflicts of Interest: The authors declare no conflict of interest.

\section{References}

1. Roupret, M.; Babjuk, M.; Burger, M.; Capoun, O.; Cohen, D.; Comperat, E.M.; Cowan, N.C.; Dominguez-Escrig, J.L.; Gontero, P.; Hugh Mostafid, A.; et al. European Association of Urology Guidelines on Upper Urinary Tract Urothelial Carcinoma: 2020 Update. Eur. Urol. 2021, 79, 62-79. [CrossRef]

2. Robertson, A.G.; Kim, J.; Al-Ahmadie, H.; Bellmunt, J.; Guo, G.; Cherniack, A.D.; Hinoue, T.; Laird, P.W.; Hoadley, K.A.; Akbani, R.; et al. Comprehensive Molecular Characterization of Muscle-Invasive Bladder Cancer. Cell 2017, 171, 540-556.e25. [CrossRef] [PubMed]

3. Therkildsen, C.; Eriksson, P.; Hoglund, M.; Jonsson, M.; Sjodahl, G.; Nilbert, M.; Liedberg, F. Molecular subtype classification of urothelial carcinoma in Lynch syndrome. Mol. Oncol. 2018, 12, 1286-1295. [CrossRef] [PubMed]

4. Chen, C.H.; Dickman, K.G.; Moriya, M.; Zavadil, J.; Sidorenko, V.S.; Edwards, K.L.; Gnatenko, D.V.; Wu, L.; Turesky, R.J.; Wu, X.R.; et al. Aristolochic acid-associated urothelial cancer in Taiwan. Proc. Natl. Acad. Sci. USA 2012, 109, 8241-8246. [CrossRef] [PubMed] 
5. Audenet, F.; Isharwal, S.; Cha, E.K.; Donoghue, M.T.A.; Drill, E.N.; Ostrovnaya, I.; Pietzak, E.J.; Sfakianos, J.P.; Bagrodia, A.; Murugan, P.; et al. Clonal Relatedness and Mutational Differences between Upper Tract and Bladder Urothelial Carcinoma. Clin. Cancer Res. 2019, 25, 967-976. [CrossRef] [PubMed]

6. Moss, T.J.; Qi, Y.; Xi, L.; Peng, B.; Kim, T.B.; Ezzedine, N.E.; Mosqueda, M.E.; Guo, C.C.; Czerniak, B.A.; Ittmann, M.; et al. Comprehensive Genomic Characterization of Upper Tract Urothelial Carcinoma. Eur. Urol. 2017, 72, 641-649. [CrossRef] [PubMed]

7. Robinson, B.D.; Vlachostergios, P.J.; Bhinder, B.; Liu, W.; Li, K.; Moss, T.J.; Bareja, R.; Park, K.; Tavassoli, P.; Cyrta, J.; et al. Upper tract urothelial carcinoma has a luminal-papillary T-cell depleted contexture and activated FGFR3 signaling. Nat. Commun. 2019, 10, 2977. [CrossRef] [PubMed]

8. Massari, F.; Ciccarese, C.; Santoni, M.; Iacovelli, R.; Mazzucchelli, R.; Piva, F.; Scarpelli, M.; Berardi, R.; Tortora, G.; Lopez-Beltran, A.; et al. Metabolic phenotype of bladder cancer. Cancer Treat. Rev. 2016, 45, 46-57. [CrossRef]

9. Urquidi, V.; Goodison, S.; Cai, Y.; Sun, Y.; Rosser, C.J. A candidate molecular biomarker panel for the detection of bladder cancer. Cancer Epidemiol. Biomark. Prev. 2012, 21, 2149-2158. [CrossRef]

10. Hoskin, P.J.; Sibtain, A.; Daley, F.M.; Wilson, G.D. GLUT1 and CAIX as intrinsic markers of hypoxia in bladder cancer: Relationship with vascularity and proliferation as predictors of outcome of ARCON. Br. J. Cancer 2003, 89, 1290-1297. [CrossRef]

11. Rosser, C.J.; Liu, L.; Sun, Y.; Villicana, P.; McCullers, M.; Porvasnik, S.; Young, P.R.; Parker, A.S.; Goodison, S. Bladder cancerassociated gene expression signatures identified by profiling of exfoliated urothelia. Cancer Epidemiol. Biomark. Prev. 2009, 18, 444-453. [CrossRef]

12. Li, P.; Yang, X.; Cheng, Y.; Zhang, X.; Yang, C.; Deng, X.; Li, P.; Tao, J.; Yang, H.; Wei, J.; et al. MicroRNA-218 Increases the Sensitivity of Bladder Cancer to Cisplatin by Targeting Glut1. Cell Physiol. Biochem. 2017, 41, 921-932. [CrossRef]

13. Fei, X.; Qi, M.; Wu, B.; Song, Y.; Wang, Y.; Li, T. MicroRNA-195-5p suppresses glucose uptake and proliferation of human bladder cancer T24 cells by regulating GLUT3 expression. FEBS Lett. 2012, 586, 392-397. [CrossRef] [PubMed]

14. Wilson, J.E. Hexokinases. Rev. Physiol. Biochem. Pharmacol. 1995, 126, 65-198.

15. Wilson, J.E. An introduction to the isoenzymes of mammalian hexokinase types I-III. Biochem. Soc. Trans. 1997, 25, 103-107. [CrossRef]

16. Wilson, J.E. Isozymes of mammalian hexokinase: Structure, subcellular localization and metabolic function. J. Exp. Biol. 2003, 206, 2049-2057. [CrossRef] [PubMed]

17. Mathupala, S.P.; Ko, Y.H.; Pedersen, P.L. Hexokinase II: Cancer's double-edged sword acting as both facilitator and gatekeeper of malignancy when bound to mitochondria. Oncogene 2006, 25, 4777-4786. [CrossRef]

18. Liu, S.; Chen, Q.; Wang, Y. MiR-125b-5p suppresses the bladder cancer progression via targeting HK2 and suppressing PI3K/AKT pathway. Hum. Cell 2020, 33, 185-194. [CrossRef] [PubMed]

19. Wang, Z.; Chen, J.; Yang, L.; Cao, M.; Yu, Y.; Zhang, R.; Quan, H.; Jiang, Q.; Hua, Y.; Wei, W.; et al. Single-Cell Sequencing-Enabled Hexokinase 2 Assay for Noninvasive Bladder Cancer Diagnosis and Screening by Detecting Rare Malignant Cells in Urine. Anal. Chem. 2020, 92, 16284-16292. [CrossRef]

20. Che, K.; Han, W.; Li, D.; Cui, S.; Zhang, M.; Yang, X.; Niu, H. Correlations between glycolysis with clinical traits and immune function in bladder urothelial carcinoma. Biosci. Rep. 2021, 41, BSR20203982. [CrossRef]

21. Li, L.; Liang, Y.; Kang, L.; Liu, Y.; Gao, S.; Chen, S.; Li, Y.; You, W.; Dong, Q.; Hong, T.; et al. Transcriptional Regulation of the Warburg Effect in Cancer by SIX1. Cancer Cell 2018, 33, 368-385.e7. [CrossRef]

22. Sun, C.M.; Xiong, D.B.; Yan, Y.; Geng, J.; Liu, M.; Yao, X.D. Genetic alteration in phosphofructokinase family promotes growth of muscle-invasive bladder cancer. Int. J. Biol. Markers 2016, 31, e286-e293. [CrossRef] [PubMed]

23. Li, J.; Wang, F.; Gao, H.; Huang, S.; Cai, F.; Sun, J. ALDOLASE A regulates invasion of bladder cancer cells via E-cadherin-EGFR signaling. J. Cell Biochem. 2019, 120, 13694-13705. [CrossRef] [PubMed]

24. Chen, T.; Huang, Z.; Tian, Y.; Wang, H.; Ouyang, P.; Chen, H.; Wu, L.; Lin, B.; He, R. Role of triosephosphate isomerase and downstream functional genes on gastric cancer. Oncol. Rep. 2017, 38, 1822-1832. [CrossRef] [PubMed]

25. Chen, T.; Huang, Z.; Tian, Y.; Lin, B.; He, R.; Wang, H.; Ouyang, P.; Chen, H.; Wu, L. Clinical significance and prognostic value of Triosephosphate isomerase expression in gastric cancer. Medicine 2017, 96, e6865. [CrossRef] [PubMed]

26. Zhang, C.; Wang, Y.Q.; Jin, G.; Wu, S.; Cui, J.; Wang, R.F. Selection of reference genes for gene expression studies in human bladder cancer using SYBR-Green quantitative polymerase chain reaction. Oncol. Lett. 2017, 14, 6001-6011. [CrossRef] [PubMed]

27. Hwang, N.R.; Yim, S.H.; Kim, Y.M.; Jeong, J.; Song, E.J.; Lee, Y.; Lee, J.H.; Choi, S.; Lee, K.J. Oxidative modifications of glyceraldehyde-3-phosphate dehydrogenase play a key role in its multiple cellular functions. Biochem. J. 2009, 423, 253-264. [CrossRef]

28. Massange-Sanchez, J.A.; Casados-Vazquez, L.E.; Juarez-Colunga, S.; Sawers, R.J.H.; Tiessen, A. The Phosphoglycerate Kinase (PGK) Gene Family of Maize (Zea mays var. B73). Plants 2020, 9, 1639. [CrossRef]

29. Wang, J.; Wang, J.; Dai, J.; Jung, Y.; Wei, C.L.; Wang, Y.; Havens, A.M.; Hogg, P.J.; Keller, E.T.; Pienta, K.J.; et al. A glycolytic mechanism regulating an angiogenic switch in prostate cancer. Cancer Res. 2007, 67, 149-159. [CrossRef]

30. Tang, S.J.; Ho, M.Y.; Cho, H.C.; Lin, Y.C.; Sun, G.H.; Chi, K.H.; Wang, Y.S.; Jhou, R.S.; Yang, W.; Sun, K.H. Phosphoglycerate kinase 1-overexpressing lung cancer cells reduce cyclooxygenase 2 expression and promote anti-tumor immunity in vivo. Int. J. Cancer 2008, 123, 2840-2848. [CrossRef] 
31. Danshina, P.V.; Geyer, C.B.; Dai, Q.; Goulding, E.H.; Willis, W.D.; Kitto, G.B.; McCarrey, J.R.; Eddy, E.M.; O’Brien, D.A. Phosphoglycerate kinase 2 (PGK2) is essential for sperm function and male fertility in mice. Biol. Reprod. 2010, 82, 136-145. [CrossRef]

32. Sharif, F.; Rasul, A.; Ashraf, A.; Hussain, G.; Younis, T.; Sarfraz, I.; Chaudhry, M.A.; Bukhari, S.A.; Ji, X.Y.; Selamoglu, Z.; et al. Phosphoglycerate mutase 1 in cancer: A promising target for diagnosis and therapy. IUBMB Life 2019, 71, 1418-1427. [CrossRef] [PubMed]

33. Ji, H.; Wang, J.; Guo, J.; Li, Y.; Lian, S.; Guo, W.; Yang, H.; Kong, F.; Zhen, L.; Guo, L.; et al. Progress in the biological function of alpha-enolase. Anim. Nutr. 2016, 2, 12-17. [CrossRef] [PubMed]

34. Seki, S.M.; Gaultier, A. Exploring Non-Metabolic Functions of Glycolytic Enzymes in Immunity. Front. Immunol. 2017, 8, 1549. [CrossRef] [PubMed]

35. Almaguel, F.A.; Sanchez, T.W.; Ortiz-Hernandez, G.L.; Casiano, C.A. Alpha-Enolase: Emerging Tumor-Associated Antigen, Cancer Biomarker, and Oncotherapeutic Target. Front. Genet. 2020, 11, 614726. [CrossRef] [PubMed]

36. Ponten, F.; Jirstrom, K.; Uhlen, M. The Human Protein Atlas-a tool for pathology. J. Pathol. 2008, 216, 387-393. [CrossRef]

37. Thul, P.J.; Lindskog, C. The human protein atlas: A spatial map of the human proteome. Protein Sci. 2018, 27, 233-244. [CrossRef]

38. Otto, A.M. Warburg effect(s)-a biographical sketch of Otto Warburg and his impacts on tumor metabolism. Cancer Metab. 2016, 4, 5. [CrossRef]

39. Prakasam, G.; Iqbal, M.A.; Bamezai, R.N.K.; Mazurek, S. Posttranslational Modifications of Pyruvate Kinase M2: Tweaks that Benefit Cancer. Front. Oncol. 2018, 8, 22. [CrossRef]

40. Noguchi, T.; Inoue, H.; Tanaka, T. The M1- and M2-type isozymes of rat pyruvate kinase are produced from the same gene by alternative RNA splicing. J. Biol. Chem. 1986, 261, 13807-13812. [CrossRef]

41. Bluemlein, K.; Gruning, N.M.; Feichtinger, R.G.; Lehrach, H.; Kofler, B.; Ralser, M. No evidence for a shift in pyruvate kinase PKM1 to PKM2 expression during tumorigenesis. Oncotarget 2011, 2, 393-400. [CrossRef] [PubMed]

42. Zahra, K.; Dey, T.; Ashish; Mishra, S.P.; Pandey, U. Pyruvate Kinase M2 and Cancer: The Role of PKM2 in Promoting Tumorigenesis. Front. Oncol. 2020, 10, 159. [CrossRef] [PubMed]

43. Shi, X.; You, L.; Luo, R.Y. Glycolytic reprogramming in cancer cells: PKM2 dimer predominance induced by pulsatile PFK-1 activity. Phys. Biol. 2019, 16, 066007. [CrossRef] [PubMed]

44. He, X.; Du, S.; Lei, T.; Li, X.; Liu, Y.; Wang, H.; Tong, R.; Wang, Y. PKM2 in carcinogenesis and oncotherapy. Oncotarget 2017, 8, 110656-110670. [CrossRef]

45. Scholtes, M.P.; de Jong, F.C.; Zuiverloon, T.C.M.; Theodorescu, D. Role of Bladder Cancer Metabolic Reprogramming in the Effectiveness of Immunotherapy. Cancers 2021, 13, 288. [CrossRef]

46. Wang, L.; Yang, X.; Li, D.; Liang, Z.; Chen, Y.; Ma, G.; Wang, Y.; Li, Y.; Liang, Y.; Niu, H. The elevated glutaminolysis of bladder cancer and $\mathrm{T}$ cells in a simulated tumor microenvironment contributes to the up-regulation of PD-L1 expression by interferon-gamma. OncoTargets Ther. 2018, 11, 7229-7243. [CrossRef]

47. Afonso, J.; Santos, L.L.; Longatto-Filho, A.; Baltazar, F. Competitive glucose metabolism as a target to boost bladder cancer immunotherapy. Nat. Rev. Urol. 2020, 17, 77-106. [CrossRef]

48. Lea, M.A.; Altayyar, M.; desBordes, C. Inhibition of Growth of Bladder Cancer Cells by 3-(3-Pyridinyl)-1-(4-pyridinyl)-2-propen1-one in Combination with Other Compounds Affecting Glucose Metabolism. Anticancer Res. 2015, 35, 5889-5899.

49. Lea, M.A.; Guzman, Y.; Desbordes, C. Inhibition of Growth by Combined Treatment with Inhibitors of Lactate Dehydrogenase and either Phenformin or Inhibitors of 6-Phosphofructo-2-kinase/Fructose-2,6-bisphosphatase 3. Anticancer Res. 2016, 36, 1479-1488.

50. Sun, Y.; Guan, Z.; Zhao, W.; Jiang, Y.; Li, Q.; Cheng, Y.; Xu, Y. Silibinin suppresses bladder cancer cell malignancy and chemoresistance in an NF-kappaB signal-dependent and signal-independent manner. Int. J. Oncol. 2017, 51, 1219-1226. [CrossRef]

51. Macoska, J.A.; Adsule, S.; Tantivejkul, K.; Wang, S.; Pienta, K.J.; Lee, C.T. -(-)Gossypol promotes the apoptosis of bladder cancer cells in vitro. Pharmacol. Res. 2008, 58, 323-331. [CrossRef]

52. Hu, K.Y.; de Wang, G.; Liu, P.F.; Cao, Y.W.; Wang, Y.H.; Yang, X.C.; Hu, C.X.; Sun, L.J.; Niu, H.T. Targeting of MCT1 and PFKFB3 influences cell proliferation and apoptosis in bladder cancer by altering the tumor microenvironment. Oncol. Rep. 2016, 36, 945-951. [CrossRef]

53. Rosenberg, J.E.; Hoffman-Censits, J.; Powles, T.; van der Heijden, M.S.; Balar, A.V.; Necchi, A.; Dawson, N.; O’Donnell, P.H.; Balmanoukian, A.; Loriot, Y.; et al. Atezolizumab in patients with locally advanced and metastatic urothelial carcinoma who have progressed following treatment with platinum-based chemotherapy: A single-arm, multicentre, phase 2 trial. Lancet 2016, 387, 1909-1920. [CrossRef]

54. Balar, A.V.; Galsky, M.D.; Rosenberg, J.E.; Powles, T.; Petrylak, D.P.; Bellmunt, J.; Loriot, Y.; Necchi, A.; Hoffman-Censits, J.; Perez-Gracia, J.L.; et al. Atezolizumab as first-line treatment in cisplatin-ineligible patients with locally advanced and metastatic urothelial carcinoma: A single-arm, multicentre, phase 2 trial. Lancet 2017, 389, 67-76. [CrossRef]

55. Sharma, P.; Retz, M.; Siefker-Radtke, A.; Baron, A.; Necchi, A.; Bedke, J.; Plimack, E.R.; Vaena, D.; Grimm, M.O.; Bracarda, S.; et al. Nivolumab in metastatic urothelial carcinoma after platinum therapy (CheckMate 275): A multicentre, single-arm, phase 2 trial. Lancet Oncol. 2017, 18, 312-322. [CrossRef]

56. Powles, T.; O’Donnell, P.H.; Massard, C.; Arkenau, H.T.; Friedlander, T.W.; Hoimes, C.J.; Lee, J.L.; Ong, M.; Sridhar, S.S.; Vogelzang, N.J.; et al. Efficacy and Safety of Durvalumab in Locally Advanced or Metastatic Urothelial Carcinoma: Updated Results from a Phase 1/2 Open-label Study. JAMA Oncol. 2017, 3, e172411. [CrossRef] 
57. Patel, M.R.; Ellerton, J.; Infante, J.R.; Agrawal, M.; Gordon, M.; Aljumaily, R.; Britten, C.D.; Dirix, L.; Lee, K.W.; Taylor, M.; et al. Avelumab in metastatic urothelial carcinoma after platinum failure (JAVELIN Solid Tumor): Pooled results from two expansion cohorts of an open-label, phase 1 trial. Lancet Oncol. 2018, 19, 51-64. [CrossRef]

58. Balar, A.V.; Castellano, D.; O’Donnell, P.H.; Grivas, P.; Vuky, J.; Powles, T.; Plimack, E.R.; Hahn, N.M.; de Wit, R.; Pang, L.; et al. First-line pembrolizumab in cisplatin-ineligible patients with locally advanced and unresectable or metastatic urothelial cancer (KEYNOTE-052): A multicentre, single-arm, phase 2 study. Lancet Oncol. 2017, 18, 1483-1492. [CrossRef]

59. Bellmunt, J.; de Wit, R.; Vaughn, D.J.; Fradet, Y.; Lee, J.L.; Fong, L.; Vogelzang, N.J.; Climent, M.A.; Petrylak, D.P.; Choueiri, T.K.; et al. Pembrolizumab as Second-Line Therapy for Advanced Urothelial Carcinoma. N. Engl. J. Med. 2017, 376, 1015-1026. [CrossRef]

60. Mossmann, D.; Park, S.; Hall, M.N. mTOR signalling and cellular metabolism are mutual determinants in cancer. Nat. Rev. Cancer 2018, 18, 744-757. [CrossRef] [PubMed]

61. Reyes-Farias, M.; Carrasco-Pozo, C. The Anti-Cancer Effect of Quercetin: Molecular Implications in Cancer Metabolism. Int. J. Mol. Sci. 2019, 20, 3177. [CrossRef] [PubMed]

62. Miao, P.; Sheng, S.; Sun, X.; Liu, J.; Huang, G. Lactate dehydrogenase A in cancer: A promising target for diagnosis and therapy. IUBMB Life 2013, 65, 904-910. [CrossRef] [PubMed]

63. Yu, M.; Yongzhi, H.; Chen, S.; Luo, X.; Lin, Y.; Zhou, Y.; Jin, H.; Hou, B.; Deng, Y.; Tu, L.; et al. The prognostic value of GLUT1 in cancers: A systematic review and meta-analysis. Oncotarget 2017, 8, 43356-43367. [CrossRef]

64. Garcia, S.N.; Guedes, R.C.; Marques, M.M. Unlocking the Potential of HK2 in Cancer Metabolism and Therapeutics. Curr. Med. Chem. 2019, 26, 7285-7322. [CrossRef] [PubMed]

65. Zou, Y.; Du, Y.; Cheng, C.; Deng, X.; Shi, Z.; Lu, X.; Hu, H.; Qiu, J.; Jiang, W. FAT10 promotes the progression of bladder cancer by upregulating HK2 through the EGFR/AKT pathway. Exp. Cell Res. 2021, 398, 112401. [CrossRef]

66. Tao, T.; Su, Q.; Xu, S.; Deng, J.; Zhou, S.; Zhuang, Y.; Huang, Y.; He, C.; He, S.; Peng, M.; et al. Down-regulation of PKM2 decreases FASN expression in bladder cancer cells through AKT/mTOR/SREBP-1c axis. J. Cell Physiol. 2019, 234, 3088-3104. [CrossRef]

67. Zhao, W.; Chang, C.; Cui, Y.; Zhao, X.; Yang, J.; Shen, L.; Zhou, J.; Hou, Z.; Zhang, Z.; Ye, C.; et al. Steroid receptor coactivator-3 regulates glucose metabolism in bladder cancer cells through coactivation of hypoxia inducible factor 1alpha. J. Biol. Chem. 2014, 289, 11219-11229. [CrossRef]

68. Wan, W.; Peng, K.; Li, M.; Qin, L.; Tong, Z.; Yan, J.; Shen, B.; Yu, C. Histone demethylase JMJD1A promotes urinary bladder cancer progression by enhancing glycolysis through coactivation of hypoxia inducible factor 1alpha. Oncogene 2017, 36, 3868-3877. [CrossRef]

69. Lima, L.; Gaiteiro, C.; Peixoto, A.; Soares, J.; Neves, M.; Santos, L.L.; Ferreira, J.A. Reference Genes for Addressing Gene Expression of Bladder Cancer Cell Models under Hypoxia: A Step Towards Transcriptomic Studies. PLoS ONE 2016, 11, e0166120. [CrossRef]

70. Chang, Y.C.; Chan, Y.C.; Chang, W.M.; Lin, Y.F.; Yang, C.J.; Su, C.Y.; Huang, M.S.; Wu, A.T.H.; Hsiao, M. Feedback regulation of ALDOA activates the HIF-1alpha/MMP9 axis to promote lung cancer progression. Cancer Lett. 2017, 403, 28-36. [CrossRef]

71. Williams, A.L.; Khadka, V.; Tang, M.; Avelar, A.; Schunke, K.J.; Menor, M.; Shohet, R.V. HIF1 mediates a switch in pyruvate kinase isoforms after myocardial infarction. Physiol. Genom. 2018, 50, 479-494. [CrossRef]

72. Wang, J.Z.; Zhu, W.; Han, J.; Yang, X.; Zhou, R.; Lu, H.C.; Yu, H.; Yuan, W.B.; Li, P.C.; Tao, J.; et al. The role of the HIF1alpha/ALYREF/PKM2 axis in glycolysis and tumorigenesis of bladder cancer. Cancer Commun. 2021, 41, 560-575. [CrossRef]

73. Aubrey, B.J.; Kelly, G.L.; Janic, A.; Herold, M.J.; Strasser, A. How does p53 induce apoptosis and how does this relate to p53-mediated tumour suppression? Cell Death Differ. 2018, 25, 104-113. [CrossRef]

74. Williams, A.B.; Schumacher, B. p53 in the DNA-Damage-Repair Process. Cold Spring Harb. Perspect. Med. 2016, 6, a026070. [CrossRef]

75. Sane, S.; Rezvani, K. Essential Roles of E3 Ubiquitin Ligases in p53 Regulation. Int. J. Mol. Sci. 2017, 18, 442. [CrossRef] [PubMed]

76. Tseng, C.H. Human insulin does not increase bladder cancer risk. PLoS ONE 2014, 9, e86517. [CrossRef] [PubMed]

77. Kim, D.; Ahn, B.N.; Kim, Y.; Hur, D.Y.; Yang, J.W.; Park, G.B.; Jang, J.E.; Lee, E.J.; Kwon, M.J.; Kim, T.N.; et al. High Glucose with Insulin Induces Cell Cycle Progression and Activation of Oncogenic Signaling of Bladder Epithelial Cells Cotreated with Metformin and Pioglitazone. J. Diabetes Res. 2019, 2019, 2376512. [CrossRef]

78. Shao, F.; Yang, X.; Wang, W.; Wang, J.; Guo, W.; Feng, X.; Shi, S.; Xue, Q.; Gao, S.; Gao, Y.; et al. Associations of PGK1 promoter hypomethylation and PGK1-mediated PDHK1 phosphorylation with cancer stage and prognosis: A TCGA pan-cancer analysis Cancer Commun. 2019, 39, 54. [CrossRef] [PubMed]

79. Li, X.; Jiang, Y.; Meisenhelder, J.; Yang, W.; Hawke, D.H.; Zheng, Y.; Xia, Y.; Aldape, K.; He, J.; Hunter, T.; et al. MitochondriaTranslocated PGK1 Functions as a Protein Kinase to Coordinate Glycolysis and the TCA Cycle in Tumorigenesis. Mol. Cell 2016, 61, 705-719. [CrossRef] [PubMed]

80. Yu, X.; Li, S. Non-metabolic functions of glycolytic enzymes in tumorigenesis. Oncogene 2017, 36, 2629-2636. [CrossRef]

81. Chang, Y.C.; Chiou, J.; Yang, Y.F.; Su, C.Y.; Lin, Y.F.; Yang, C.N.; Lu, P.J.; Huang, M.S.; Yang, C.J.; Hsiao, M. Therapeutic Targeting of Aldolase a Interactions Inhibits Lung Cancer Metastasis and Prolongs Survival. Cancer Res. 2019, 79, 4754-4766. [CrossRef]

82. Huang, K.; Liang, Q.; Zhou, Y.; Jiang, L.L.; Gu, W.M.; Luo, M.Y.; Tang, Y.B.; Wang, Y.; Lu, W.; Huang, M.; et al. A Novel Allosteric Inhibitor of Phosphoglycerate Mutase 1 Suppresses Growth and Metastasis of Non-Small-Cell Lung Cancer. Cell Metab. 2019, 30, 1107-1119.e8. [CrossRef] 
83. Chang, Y.C.; Chan, M.H.; Li, C.H.; Yang, C.J.; Tseng, Y.W.; Tsai, H.F.; Chiou, J.; Hsiao, M. Metabolic protein phosphoglycerate kinase 1 confers lung cancer migration by directly binding HIV Tat specific factor 1. Cell Death Discov. 2021, 7, 135. [CrossRef]

84. Liu, S.E.; Hu, J.C.; Zhang, H.; Xu, P.; Wan, W.; Zheng, M.Y.; Yu, K.Q.; Ding, H.; Jiang, H.L.; Zhou, L.; et al. Conformation and dynamics of the C-terminal region in human phosphoglycerate mutase 1. Acta Pharmacol. Sin. 2017, 38, 1673-1682. [CrossRef] [PubMed]

85. Zhai, D.; Chin, K.; Wang, M.; Liu, F. Disruption of the nuclear p53-GAPDH complex protects against ischemia-induced neuronal damage. Mol. Brain 2014, 7, 20. [CrossRef] [PubMed]

86. Butera, G.; Pacchiana, R.; Mullappilly, N.; Margiotta, M.; Bruno, S.; Conti, P.; Riganti, C.; Donadelli, M. Mutant p53 prevents GAPDH nuclear translocation in pancreatic cancer cells favoring glycolysis and 2-deoxyglucose sensitivity. Biochim. Biophys. Acta Mol. Cell Res. 2018, 1865, 1914-1923. [CrossRef] [PubMed]

87. Funasaka, T.; Raz, A. The role of autocrine motility factor in tumor and tumor microenvironment. Cancer Metastasis Rev. 2007, 26, 725-735. [CrossRef] [PubMed]

88. Leto, D.; Saltiel, A.R. Regulation of glucose transport by insulin: Traffic control of GLUT4. Nat. Rev. Mol. Cell Biol. 2012, 13, 383-396. [CrossRef] [PubMed]

89. Hou, X.; Liu, Y.; Liu, H.; Chen, X.; Liu, M.; Che, H.; Guo, F.; Wang, C.; Zhang, D.; Wu, J.; et al. PERK silence inhibits glioma cell growth under low glucose stress by blockage of p-AKT and subsequent HK2's mitochondria translocation. Sci. Rep. 2015, 5, 9065. [CrossRef] [PubMed]

90. Mamczur, P.; Gamian, A.; Kolodziej, J.; Dziegiel, P.; Rakus, D. Nuclear localization of aldolase A correlates with cell proliferation. Biochim. Biophys. Acta 2013, 1833, 2812-2822. [CrossRef]

91. Huang, Q.; Lan, F.; Zheng, Z.; Xie, F.; Han, J.; Dong, L.; Xie, Y.; Zheng, F. Akt2 kinase suppresses glyceraldehyde-3-phosphate dehydrogenase (GAPDH)-mediated apoptosis in ovarian cancer cells via phosphorylating GAPDH at threonine 237 and decreasing its nuclear translocation. J. Biol. Chem. 2011, 286, 42211-42220. [CrossRef] [PubMed]

92. Feo, S.; Arcuri, D.; Piddini, E.; Passantino, R.; Giallongo, A. ENO1 gene product binds to the c-myc promoter and acts as a transcriptional repressor: Relationship with Myc promoter-binding protein 1 (MBP-1). FEBS Lett. 2000, 473, 47-52. [CrossRef]

93. Balihodzic, A.; Barth, D.A.; Prinz, F.; Pichler, M. Involvement of Long Non-Coding RNAs in Glucose Metabolism in Cancer. Cancers 2021, 13, 977. [CrossRef] [PubMed]

94. Hu, R.; Zhong, P.; Xiong, L.; Duan, L. Long Noncoding RNA Cancer Susceptibility Candidate 8 Suppresses the Proliferation of Bladder Cancer Cells via Regulating Glycolysis. DNA Cell Biol. 2017, 36, 767-774. [CrossRef]

95. Jiang, S.; Zhang, L.F.; Zhang, H.W.; Hu, S.; Lu, M.H.; Liang, S.; Li, B.; Li, Y.; Li, D.; Wang, E.D.; et al. A novel miR-155/miR-143 cascade controls glycolysis by regulating hexokinase 2 in breast cancer cells. EMBO J. 2012, 31, 1985-1998. [CrossRef]

96. Li, Z.; Li, X.; Wu, S.; Xue, M.; Chen, W. Long non-coding RNA UCA1 promotes glycolysis by upregulating hexokinase 2 through the mTOR-STAT3/microRNA143 pathway. Cancer Sci. 2014, 105, 951-955. [CrossRef]

97. Guancial, E.A.; Bellmunt, J.; Yeh, S.; Rosenberg, J.E.; Berman, D.M. The evolving understanding of microRNA in bladder cancer. Urol. Oncol. 2014, 32, 41.e31-41.e40. [CrossRef] [PubMed]

98. Dyrskjot, L.; Ostenfeld, M.S.; Bramsen, J.B.; Silahtaroglu, A.N.; Lamy, P.; Ramanathan, R.; Fristrup, N.; Jensen, J.L.; Andersen, C.L.; Zieger, K.; et al. Genomic profiling of microRNAs in bladder cancer: miR-129 is associated with poor outcome and promotes cell death in vitro. Cancer Res. 2009, 69, 4851-4860. [CrossRef]

99. Miyamoto, K.; Seki, N.; Matsushita, R.; Yonemori, M.; Yoshino, H.; Nakagawa, M.; Enokida, H. Tumour-suppressive miRNA-26a$5 p$ and miR-26b-5p inhibit cell aggressiveness by regulating PLOD2 in bladder cancer. Br. J. Cancer 2016, 115, 354-363. [CrossRef] [PubMed]

100. Yang, X.; Cheng, Y.; Li, P.; Tao, J.; Deng, X.; Zhang, X.; Gu, M.; Lu, Q.; Yin, C. A lentiviral sponge for miRNA-21 diminishes aerobic glycolysis in bladder cancer T24 cells via the PTEN/PI3K/AKT/mTOR axis. Tumour Biol. 2015, 36, 383-391. [CrossRef]

101. Rahmat, J.N.; Esuvaranathan, K.; Mahendran, R. Bacillus Calmette-Guerin induces rapid gene expression changes in human bladder cancer cell lines that may modulate its survival. Oncol Lett. 2018, 15, 9231-9241. [PubMed]

102. Guo, C.; Liu, S.; Sun, M.Z. Novel insight into the role of GAPDH playing in tumor. Clin. Transl. Oncol. 2013, 15, 167-172. [CrossRef] [PubMed]

103. Wu, S.T.; Liu, B.; Ai, Z.Z.; Hong, Z.C.; You, P.T.; Wu, H.Z.; Yang, Y.F. Esculetin Inhibits Cancer Cell Glycolysis by Binding Tumor PGK2, GPD2, and GPI. Front. Pharmacol. 2020, 11, 379. [CrossRef] [PubMed]

104. Ji, M.; Wang, Z.; Chen, J.; Gu, L.; Chen, M.; Ding, Y.; Liu, T. Up-regulated ENO1 promotes the bladder cancer cell growth and proliferation via regulating beta-catenin. Biosci. Rep. 2019, 39, BSR20190503. [CrossRef] [PubMed]

105. Xie, R.; Chen, X.; Chen, Z.; Huang, M.; Dong, W.; Gu, P.; Zhang, J.; Zhou, Q.; Dong, W.; Han, J.; et al. Polypyrimidine tract binding protein 1 promotes lymphatic metastasis and proliferation of bladder cancer via alternative splicing of MEIS2 and PKM. Cancer Lett. 2019, 449, 31-44. [CrossRef]

106. Yan, Q.; Zeng, P.; Zhou, X.; Zhao, X.; Chen, R.; Qiao, J.; Feng, L.; Zhu, Z.; Zhang, G.; Chen, C. RBMX suppresses tumorigenicity and progression of bladder cancer by interacting with the hnRNP A1 protein to regulate PKM alternative splicing. Oncogene 2021, 40, 2635-2650. [CrossRef]

107. Taoka, Y.; Matsumoto, K.; Ohashi, K.; Minamida, S.; Hagiwara, M.; Nagi, S.; Saito, T.; Kodera, Y.; Iwamura, M. Protein expression profile related to cisplatin resistance in bladder cancer cell lines detected by two-dimensional gel electrophoresis. Biomed. Res. 2015, 36, 253-261. [CrossRef] 
108. Wang, X.; Zhang, F.; Wu, X.R. Inhibition of Pyruvate Kinase M2 Markedly Reduces Chemoresistance of Advanced Bladder Cancer to Cisplatin. Sci. Rep. 2017, 7, 45983. [CrossRef]

109. Liu, W.; Woolbright, B.L.; Pirani, K.; Didde, R.; Abbott, E.; Kaushik, G.; Martin, P.; Hamilton-Reeves, J.; Taylor, J.A., 3rd; Holzbeierlein, J.M.; et al. Tumor M2-PK: A novel urine marker of bladder cancer. PLoS ONE 2019, 14, e0218737. [CrossRef]

110. Zhou, H.; Wang, X.; Mo, L.; Liu, Y.; He, F.; Zhang, F.; Huang, K.H.; Wu, X.R. Role of isoenzyme M2 of pyruvate kinase in urothelial tumorigenesis. Oncotarget 2016, 7, 23947-23960. [CrossRef]

111. Huang, C.; Huang, Z.; Bai, P.; Luo, G.; Zhao, X.; Wang, X. Expression of pyruvate kinase M2 in human bladder cancer and its correlation with clinical parameters and prognosis. OncoTargets Ther. 2018, 11, 2075-2082. [CrossRef]

112. Lu, W.; Gao, J.; Yang, J.; Cao, Y.; Jiang, L.; Li, M.; Zhang, Y.; Zhou, J.; Liu, Y. Down-Regulated Phosphoglycerate Kinase 1 Expression Is Associated with Poor Prognosis in Patients with Gallbladder Cancer. Medicine 2015, 94, e2244. [CrossRef]

113. Yun, S.J.; Jo, S.W.; Ha, Y.S.; Lee, O.J.; Kim, W.T.; Kim, Y.J.; Lee, S.C.; Kim, W.J. PFKFB4 as a prognostic marker in non-muscleinvasive bladder cancer. Urol. Oncol. 2012, 30, 893-899. [CrossRef]

114. Al-Maghrabi, J.A.; Qureshi, I.A.; Khabaz, M.N. Immunhistochemical expression of GLUT1 is associated with low grade and low stage of urinary bladder cancer. Int. J. Clin. Exp. Pathol. 2019, 12, 3049-3057.

115. Reis, H.; Tschirdewahn, S.; Szarvas, T.; Rubben, H.; Schmid, K.W.; Grabellus, F. Expression of GLUT1 is associated with increasing grade of malignancy in non-invasive and invasive urothelial carcinomas of the bladder. Oncol. Lett. 2011, 2, 1149-1153. [CrossRef] [PubMed]

116. Sjodahl, G.; Eriksson, P.; Patschan, O.; Marzouka, N.A.; Jakobsson, L.; Bernardo, C.; Lovgren, K.; Chebil, G.; Zwarthoff, E.; Liedberg, F.; et al. Molecular changes during progression from nonmuscle invasive to advanced urothelial carcinoma. Int. J. Cancer 2020, 146, 2636-2647. [CrossRef] [PubMed]

117. Saito, R.; Smith, C.C.; Utsumi, T.; Bixby, L.M.; Kardos, J.; Wobker, S.E.; Stewart, K.G.; Chai, S.; Manocha, U.; Byrd, K.M.; et al. Molecular Subtype-Specific Immunocompetent Models of High-Grade Urothelial Carcinoma Reveal Differential Neoantigen Expression and Response to Immunotherapy. Cancer Res. 2018, 78, 3954-3968. [CrossRef] [PubMed]

118. Chiang, I.N.; Pu, Y.S.; Huang, C.Y.; Young, T.H. Far infrared radiation promotes rabbit renal proximal tubule cell proliferation and functional characteristics, and protects against cisplatin-induced nephrotoxicity. PLoS ONE 2017, 12, e0180872. [CrossRef]

119. Datta, J.; Damodaran, S.; Parks, H.; Ocrainiciuc, C.; Miya, J.; Yu, L.; Gardner, E.P.; Samorodnitsky, E.; Wing, M.R.; Bhatt, D.; et al. Akt Activation Mediates Acquired Resistance to Fibroblast Growth Factor Receptor Inhibitor BGJ398. Mol. Cancer Ther. 2017, 16, 614-624. [CrossRef] [PubMed]

120. Tanaka, N.; Kosaka, T.; Miyazaki, Y.; Mikami, S.; Niwa, N.; Otsuka, Y.; Minamishima, Y.A.; Mizuno, R.; Kikuchi, E.; Miyajima, A.; et al. Acquired platinum resistance involves epithelial to mesenchymal transition through ubiquitin ligase FBXO32 dysregulation. JCI Insight 2016, 1, e83654. [CrossRef]

121. Lee, Y.H.; Lee, M.M.; De Silva, D.M.; Roy, A.; Wright, C.E.; Wong, T.K.; Costello, R.; Olaku, O.; Grubb, R.L., 3rd; Agarwal, P.K.; et al. Autocrine signaling by receptor tyrosine kinases in urothelial carcinoma of the bladder. PLoS ONE 2021, 16, e0241766.

122. Lee, H.Y.; Li, C.C.; Li, W.M.; Hsu, Y.L.; Yeh, H.C.; Ke, H.L.; Yeh, B.W.; Huang, C.N.; Li, C.F.; Kuo, P.L.; et al. Identification of potential genes in upper tract urothelial carcinoma using next-generation sequencing with bioinformatics and in vitro analyses. PeerJ 2021, 9, e11343. [CrossRef]

123. Chen, X.; Li, A.; Sun, B.F.; Yang, Y.; Han, Y.N.; Yuan, X.; Chen, R.X.; Wei, W.S.; Liu, Y.; Gao, C.C.; et al. 5-methylcytosine promotes pathogenesis of bladder cancer through stabilizing mRNAs. Nat. Cell Biol. 2019, 21, 978-990. [CrossRef] [PubMed]

124. Cai, E.Y.; Garcia, J.; Liu, Y.; Vakar-Lopez, F.; Arora, S.; Nguyen, H.M.; Lakely, B.; Brown, L.; Wong, A.; Montgomery, B.; et al. A bladder cancer patient-derived xenograft displays aggressive growth dynamics in vivo and in organoid culture. Sci. Rep. 2021, 11, 4609. [CrossRef] [PubMed]

125. Chen, H.; Liu, Y.; Cao, C.; Xi, H.; Chen, W.; Zheng, W.; Dong, X.; Zheng, S.; Li, L.; Ma, J.; et al. CYR61 as a potential biomarker for the preoperative identification of muscle-invasive bladder cancers. Ann. Transl. Med. 2021, 9, 761. [CrossRef] [PubMed]

126. Fujimoto, M.; Arai, E.; Tsumura, K.; Yotani, T.; Yamada, Y.; Takahashi, Y.; Maeshima, A.M.; Fujimoto, H.; Yoshida, T.; Kanai, Y. Establishment of diagnostic criteria for upper urinary tract urothelial carcinoma based on genome-wide DNA methylation analysis. Epigenetics 2020, 15, 1289-1301. [CrossRef]

127. Kim, S.; Kim, Y.; Kong, J.; Kim, E.; Choi, J.H.; Yuk, H.D.; Lee, H.; Kim, H.R.; Lee, K.H.; Kang, M.; et al. Epigenetic regulation of mammalian Hedgehog signaling to the stroma determines the molecular subtype of bladder cancer. Elife 2019, 8, e43024. [CrossRef]

128. Lee, S.H.; Hu, W.; Matulay, J.T.; Silva, M.V.; Owczarek, T.B.; Kim, K.; Chua, C.W.; Barlow, L.J.; Kandoth, C.; Williams, A.B.; et al. Tumor Evolution and Drug Response in Patient-Derived Organoid Models of Bladder Cancer. Cell 2018, 173, 515-528.e17. [CrossRef]

129. Jou, Y.C.; Lin, G.L.; Lin, H.Y.; Huang, W.H.; Chuang, Y.M.; Lin, R.I.; Chen, P.C.; Wu, S.F.; Shen, C.H.; Chan, M.W.Y. Cyproheptadine, an epigenetic modifier, exhibits anti-tumor activity by reversing the epigenetic silencing of IRF6 in urothelial carcinoma. Cancer Cell Int. 2021, 21, 226. [CrossRef]

130. Ooki, A.; Del Carmen Rodriguez Pena, M.; Marchionni, L.; Dinalankara, W.; Begum, A.; Hahn, N.M.; VandenBussche, C.J.; Rasheed, Z.A.; Mao, S.; Netto, G.J.; et al. YAP1 and COX2 Coordinately Regulate Urothelial Cancer Stem-like Cells. Cancer Res. 2018, 78, 168-181. [CrossRef] 
131. Pinkerneil, M.; Hoffmann, M.J.; Deenen, R.; Kohrer, K.; Arent, T.; Schulz, W.A.; Niegisch, G. Inhibition of Class I Histone Deacetylases 1 and 2 Promotes Urothelial Carcinoma Cell Death by Various Mechanisms. Mol. Cancer Ther. 2016, 15, $299-312$. [CrossRef]

132. Hsieh, H.Y.; Jou, Y.C.; Tung, C.L.; Tsai, Y.S.; Wang, Y.H.; Chi, C.L.; Lin, R.I.; Hung, S.K.; Chuang, Y.M.; Wu, S.F.; et al. Epigenetic silencing of the dual-role signal mediator, ANGPTL4 in tumor tissues and its overexpression in the urothelial carcinoma microenvironment. Oncogene 2018, 37, 673-686. [CrossRef]

133. Kim, P.H.; Cha, E.K.; Sfakianos, J.P.; Iyer, G.; Zabor, E.C.; Scott, S.N.; Ostrovnaya, I.; Ramirez, R.; Sun, A.; Shah, R.; et al. Genomic predictors of survival in patients with high-grade urothelial carcinoma of the bladder. Eur. Urol. 2015, 67, 198-201. [CrossRef] [PubMed]

134. Iyer, G.; Al-Ahmadie, H.; Schultz, N.; Hanrahan, A.J.; Ostrovnaya, I.; Balar, A.V.; Kim, P.H.; Lin, O.; Weinhold, N.; Sander, C.; et al. Prevalence and co-occurrence of actionable genomic alterations in high-grade bladder cancer. J. Clin. Oncol. 2013, 31, 3133-3140. [CrossRef] [PubMed]

135. Al-Ahmadie, H.A.; Iyer, G.; Lee, B.H.; Scott, S.N.; Mehra, R.; Bagrodia, A.; Jordan, E.J.; Gao, S.P.; Ramirez, R.; Cha, E.K.; et al. Frequent somatic CDH1 loss-of-function mutations in plasmacytoid variant bladder cancer. Nat. Genet. 2016, 48, 356-358. [CrossRef] [PubMed]

136. Guo, G.; Sun, X.; Chen, C.; Wu, S.; Huang, P.; Li, Z.; Dean, M.; Huang, Y.; Jia, W.; Zhou, Q.; et al. Whole-genome and whole-exome sequencing of bladder cancer identifies frequent alterations in genes involved in sister chromatid cohesion and segregation. Nat. Genet. 2013, 45, 1459-1463. [CrossRef]

137. Van Allen, E.M.; Mouw, K.W.; Kim, P.; Iyer, G.; Wagle, N.; Al-Ahmadie, H.; Zhu, C.; Ostrovnaya, I.; Kryukov, G.V.; O'Connor, K.W.; et al. Somatic ERCC2 mutations correlate with cisplatin sensitivity in muscle-invasive urothelial carcinoma. Cancer Discov. 2014, 4, 1140-1153. [CrossRef] [PubMed]

138. Cancer Genome Atlas Research, N. Comprehensive molecular characterization of urothelial bladder carcinoma. Nature 2014, 507, 315-322. [CrossRef] [PubMed]

139. Hoadley, K.A.; Yau, C.; Hinoue, T.; Wolf, D.M.; Lazar, A.J.; Drill, E.; Shen, R.; Taylor, A.M.; Cherniack, A.D.; Thorsson, V.; et al. Cell-of-Origin Patterns Dominate the Molecular Classification of 10,000 Tumors from 33 Types of Cancer. Cell 2018, 173, 291-304.e6. [CrossRef]

140. Ellrott, K.; Bailey, M.H.; Saksena, G.; Covington, K.R.; Kandoth, C.; Stewart, C.; Hess, J.; Ma, S.; Chiotti, K.E.; McLellan, M.; et al. Scalable Open Science Approach for Mutation Calling of Tumor Exomes Using Multiple Genomic Pipelines. Cell Syst. 2018, 6, 271-281.e7. [CrossRef]

141. Taylor, A.M.; Shih, J.; Ha, G.; Gao, G.F.; Zhang, X.; Berger, A.C.; Schumacher, S.E.; Wang, C.; Hu, H.; Liu, J.; et al. Genomic and Functional Approaches to Understanding Cancer Aneuploidy. Cancer Cell 2018, 33, 676-689.e3. [CrossRef] [PubMed]

142. Liu, J.; Lichtenberg, T.; Hoadley, K.A.; Poisson, L.M.; Lazar, A.J.; Cherniack, A.D.; Kovatich, A.J.; Benz, C.C.; Levine, D.A.; Lee, A.V.; et al. An Integrated TCGA Pan-Cancer Clinical Data Resource to Drive High-Quality Survival Outcome Analytics. Cell 2018, 173, 400-416.e11. [CrossRef] [PubMed]

143. Pietzak, E.J.; Bagrodia, A.; Cha, E.K.; Drill, E.N.; Iyer, G.; Isharwal, S.; Ostrovnaya, I.; Baez, P.; Li, Q.; Berger, M.F.; et al. Nextgeneration Sequencing of Nonmuscle Invasive Bladder Cancer Reveals Potential Biomarkers and Rational Therapeutic Targets. Eur. Urol. 2017, 72, 952-959. [CrossRef] [PubMed]

144. Faltas, B.M.; Prandi, D.; Tagawa, S.T.; Molina, A.M.; Nanus, D.M.; Sternberg, C.; Rosenberg, J.; Mosquera, J.M.; Robinson, B.; Elemento, O.; et al. Clonal evolution of chemotherapy-resistant urothelial carcinoma. Nat. Genet. 2016, 48, 1490-1499. [CrossRef] [PubMed]

145. Sfakianos, J.P.; Cha, E.K.; Iyer, G.; Scott, S.N.; Zabor, E.C.; Shah, R.H.; Ren, Q.; Bagrodia, A.; Kim, P.H.; Hakimi, A.A.; et al. Genomic Characterization of Upper Tract Urothelial Carcinoma. Eur. Urol. 2015, 68, 970-977. [CrossRef]

146. Su, X.; Lu, X.; Bazai, S.K.; Comperat, E.; Mouawad, R.; Yao, H.; Roupret, M.; Spano, J.P.; Khayat, D.; Davidson, I.; et al. Comprehensive integrative profiling of upper tract urothelial carcinomas. Genome Biol. 2021, 22, 7. [CrossRef]

147. Kim, K.; Hu, W.; Audenet, F.; Almassi, N.; Hanrahan, A.J.; Murray, K.; Bagrodia, A.; Wong, N.; Clinton, T.N.; Dason, S.; et al. Modeling biological and genetic diversity in upper tract urothelial carcinoma with patient derived xenografts. Nat. Commun. 2020, 11, 1975. [CrossRef]

148. Peng, X.C.; Gong, F.M.; Chen, Y.; Qiu, M.; Cheng, K.; Tang, J.; Ge, J.; Chen, N.; Zeng, H.; Liu, J.Y. Proteomics identification of PGAM1 as a potential therapeutic target for urothelial bladder cancer. J. Proteom. 2016, 132, 85-92. [CrossRef]

149. Evans, M.J.; Saghatelian, A.; Sorensen, E.J.; Cravatt, B.F. Target discovery in small-molecule cell-based screens by in situ proteome reactivity profiling. Nat. Biotechnol. 2005, 23, 1303-1307. [CrossRef]

150. Li, X.; Tang, S.; Wang, Q.Q.; Leung, E.L.; Jin, H.; Huang, Y.; Liu, J.; Geng, M.; Huang, M.; Yuan, S.; et al. Identification of Epigallocatechin-3- Gallate as an Inhibitor of Phosphoglycerate Mutase 1. Front. Pharmacol. 2017, 8, 325. [CrossRef] [PubMed]

151. Wang, P.; Jiang, L.; Cao, Y.; Zhang, X.; Chen, B.; Zhang, S.; Huang, K.; Ye, D.; Zhou, L. Xanthone derivatives as phosphoglycerate mutase 1 inhibitors: Design, synthesis, and biological evaluation. Bioorgan. Med. Chem. 2018, 26, 1961-1970. [CrossRef]

152. Nelson, J.A.; Falk, R.E. The efficacy of phloridzin and phloretin on tumor cell growth. Anticancer Res. 1993, 13, $2287-2292$.

153. Nelson, J.A.; Falk, R.E. Phloridzin and phloretin inhibition of 2-deoxy-D-glucose uptake by tumor cells in vitro and in vivo. Anticancer Res. 1993, 13, 2293-2299. 
154. Orsolic, N.; Karac, I.; Sirovina, D.; Kukolj, M.; Kunstic, M.; Gajski, G.; Garaj-Vrhovac, V.; Stajcar, D. Chemotherapeutic potential of quercetin on human bladder cancer cells. J. Environ. Sci. Health Part A Toxic/Hazard. Subst. Environ. Eng. 2016, 51, 776-781. [CrossRef]

155. Su, Q.; Peng, M.; Zhang, Y.; Xu, W.; Darko, K.O.; Tao, T.; Huang, Y.; Tao, X.; Yang, X. Quercetin induces bladder cancer cells apoptosis by activation of AMPK signaling pathway. Am. J. Cancer Res. 2016, 6, 498-508.

156. Chang, Y.C.; Chi, L.H.; Chang, W.M.; Su, C.Y.; Lin, Y.F.; Chen, C.L.; Chen, M.H.; Chang, P.M.; Wu, A.T.; Hsiao, M. Glucose transporter 4 promotes head and neck squamous cell carcinoma metastasis through the TRIM24-DDX58 axis. J. Hematol. Oncol. 2017, 10, 11. [CrossRef]

157. Konstantakou, E.G.; Voutsinas, G.E.; Velentzas, A.D.; Basogianni, A.S.; Paronis, E.; Balafas, E.; Kostomitsopoulos, N.; Syrigos, K.N.; Anastasiadou, E.; Stravopodis, D.J. 3-BrPA eliminates human bladder cancer cells with highly oncogenic signatures via engagement of specific death programs and perturbation of multiple signaling and metabolic determinants. Mol. Cancer 2015, 14, 135. [CrossRef] [PubMed]

158. Amara, C.S.; Vantaku, V.; Lotan, Y.; Putluri, N. Recent advances in the metabolomic study of bladder cancer. Expert Rev. Proteom. 2019, 16, 315-324. [CrossRef]

159. Verma, N.; Pink, M.; Boland, S.; Rettenmeier, A.W.; Schmitz-Spanke, S. Benzo[a]pyrene-induced metabolic shift from glycolysis to pentose phosphate pathway in the human bladder cancer cell line RT4. Sci. Rep. 2017, 7, 9773. [CrossRef]

160. Wu, C.H.; Ho, Y.S.; Tsai, C.Y.; Wang, Y.J.; Tseng, H.; Wei, P.L.; Lee, C.H.; Liu, R.S.; Lin, S.Y. In vitro and in vivo study of phloretin-induced apoptosis in human liver cancer cells involving inhibition of type II glucose transporter. Int. J. Cancer 2009, 124, 2210-2219. [CrossRef] [PubMed]

161. Akins, N.S.; Nielson, T.C.; Le, H.V. Inhibition of Glycolysis and Glutaminolysis: An Emerging Drug Discovery Approach to Combat Cancer. Curr. Top. Med. Chem. 2018, 18, 494-504. [CrossRef] [PubMed]

162. Choi, B.Y. Biochemical Basis of Anti-Cancer-Effects of Phloretin-A Natural Dihydrochalcone. Molecules 2019, 24, 278. [CrossRef]

163. Hamilton, K.E.; Rekman, J.F.; Gunnink, L.K.; Busscher, B.M.; Scott, J.L.; Tidball, A.M.; Stehouwer, N.R.; Johnecheck, G.N.; Looyenga, B.D.; Louters, L.L. Quercetin inhibits glucose transport by binding to an exofacial site on GLUT1. Biochimie 2018, 151, 107-114. [CrossRef] [PubMed]

164. Ritterson Lew, C.; Guin, S.; Theodorescu, D. Targeting glycogen metabolism in bladder cancer. Nat. Rev. Urol. 2015, 12, 383-391.

165. Gong, L.; Wei, Y.; Yu, X.; Peng, J.; Leng, X. 3-Bromopyruvic acid, a hexokinase II inhibitor, is an effective antitumor agent on the hepatoma cells: In vitro and in vivo findings. Anticancer Agents Med. Chem. 2014, 14, 771-776. [CrossRef]

166. Pajak, B.; Siwiak, E.; Soltyka, M.; Priebe, A.; Zielinski, R.; Fokt, I.; Ziemniak, M.; Jaskiewicz, A.; Borowski, R.; Domoradzki, T.; et al. 2-Deoxy-d-Glucose and Its Analogs: From Diagnostic to Therapeutic Agents. Int. J. Mol. Sci. 2019, 21, 234. [CrossRef]

167. Bailey, K.M.; Wojtkowiak, J.W.; Hashim, A.I.; Gillies, R.J. Targeting the metabolic microenvironment of tumors. Adv. Pharm. 2012, 65, 63-107.

168. Emini Veseli, B.; Perrotta, P.; Van Wielendaele, P.; Lambeir, A.M.; Abdali, A.; Bellosta, S.; Monaco, G.; Bultynck, G.; Martinet, W.; De Meyer, G.R.Y. Small molecule 3PO inhibits glycolysis but does not bind to 6-phosphofructo-2-kinase/fructose-2,6-bisphosphatase3 (PFKFB3). FEBS Lett. 2020, 594, 3067-3075. [CrossRef]

169. Chan, A.K.; Bruce, J.I.; Siriwardena, A.K. Glucose metabolic phenotype of pancreatic cancer. World J. Gastroenterol. 2016, 22, 3471-3485. [CrossRef]

170. Schmidt, M.M.; Dringen, R. Differential effects of iodoacetamide and iodoacetate on glycolysis and glutathione metabolism of cultured astrocytes. Front. Neuroenerg. 2009, 1, 1. [CrossRef]

171. Liu, Y.; Gong, R.; Liu, X.; Zhang, P.; Zhang, Q.; Cai, Y.S.; Deng, Z.; Winkler, M.; Wu, J.; Chen, W. Discovery and characterization of the tubercidin biosynthetic pathway from Streptomyces tubercidicus NBRC 13090. Microb. Cell Fact. 2018, 17, 131. [CrossRef]

172. Scatena, R.; Bottoni, P.; Pontoglio, A.; Mastrototaro, L.; Giardina, B. Glycolytic enzyme inhibitors in cancer treatment. Expert Opin. Investig. Drugs 2008, 17, 1533-1545. [CrossRef] [PubMed]

173. Shao, F.; Zou, Y.; Cai, L.; Wang, X.; Chen, Y. Unexpected Detection of Urinary Bladder Cancer on Dual Phase 18F-NaF PET/CT in a Patient with Back Pain. Clin. Nucl. Med. 2016, 41, 902-904. [CrossRef] [PubMed]

174. Li, W.; Liu, J.; Zhao, Y. PKM2 inhibitor shikonin suppresses TPA-induced mitochondrial malfunction and proliferation of skin epidermal JB6 cells. Mol. Carcinog. 2014, 53, 403-412. [CrossRef] [PubMed]

175. Zhao, X.; Zhu, Y.; Hu, J.; Jiang, L.; Li, L.; Jia, S.; Zen, K. Shikonin Inhibits Tumor Growth in Mice by Suppressing Pyruvate Kinase M2-mediated Aerobic Glycolysis. Sci. Rep. 2018, 8, 14517. [CrossRef]

176. Wang, Y.; Hao, F.; Nan, Y.; Qu, L.; Na, W.; Jia, C.; Chen, X. PKM2 Inhibitor Shikonin Overcomes the Cisplatin Resistance in Bladder Cancer by Inducing Necroptosis. Int. J. Biol. Sci. 2018, 14, 1883-1891. [CrossRef]

177. Le Gouvello, S.; Colard, O.; Theodorou, I.; Bismuth, G.; Tarantino, N.; Debre, P. CD2 triggering stimulates a phospholipase A2 activity beside the phospholipase C pathway in human T lymphocytes. J. Immunol. 1990, 144, 2359-2364.

178. Powers, J.L.; Kiesman, N.E.; Tran, C.M.; Brown, J.H.; Bevilacqua, V.L. Lactate dehydrogenase kinetics and inhibition using a microplate reader. Biochem. Mol. Biol. Educ. 2007, 35, 287-292. [CrossRef]

179. Giovannetti, E.; Leon, L.G.; Gomez, V.E.; Zucali, P.A.; Minutolo, F.; Peters, G.J. A specific inhibitor of lactate dehydrogenase overcame the resistance toward gemcitabine in hypoxic mesothelioma cells, and modulated the expression of the human equilibrative transporter-1. Nucleosides Nucleotides Nucleic Acids 2016, 35, 643-651. [CrossRef] 
180. Nakanishi, Y.; Mizuno, H.; Sase, H.; Fujii, T.; Sakata, K.; Akiyama, N.; Aoki, Y.; Aoki, M.; Ishii, N. ERK Signal Suppression and Sensitivity to CH5183284/Debio 1347, a Selective FGFR Inhibitor. Mol. Cancer Ther. 2015, 14, 2831-2839. [CrossRef]

181. Garje, R.; An, J.; Obeidat, M.; Kumar, K.; Yasin, H.A.; Zakharia, Y. Fibroblast Growth Factor Receptor (FGFR) Inhibitors in Urothelial Cancer. Oncologist 2020, 25, e1711-e1719. [CrossRef] [PubMed] 